\title{
TECHNOLOGY UTILIZATION
}

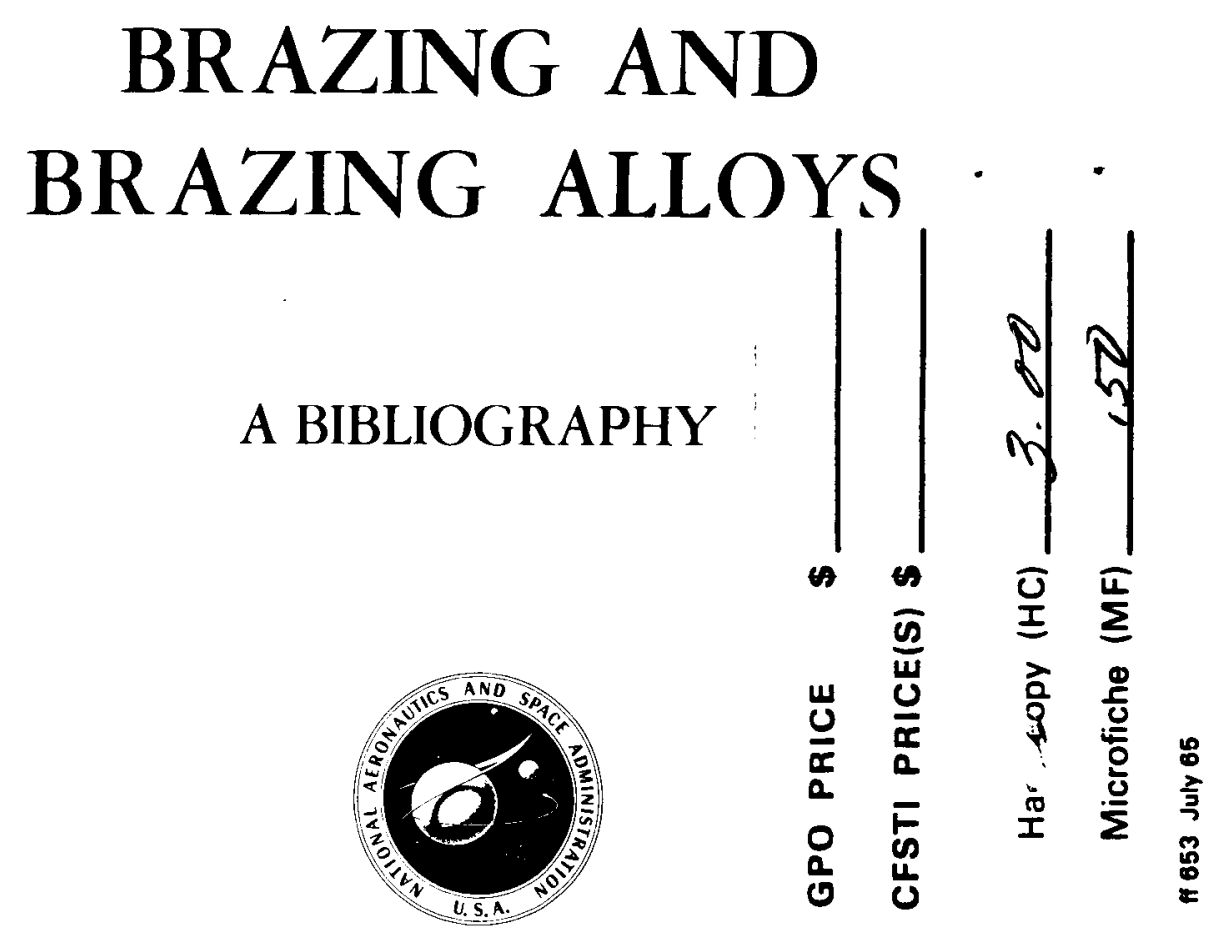

NATIONAL AERONAUTICS AND SPACE ADMINISTRATION
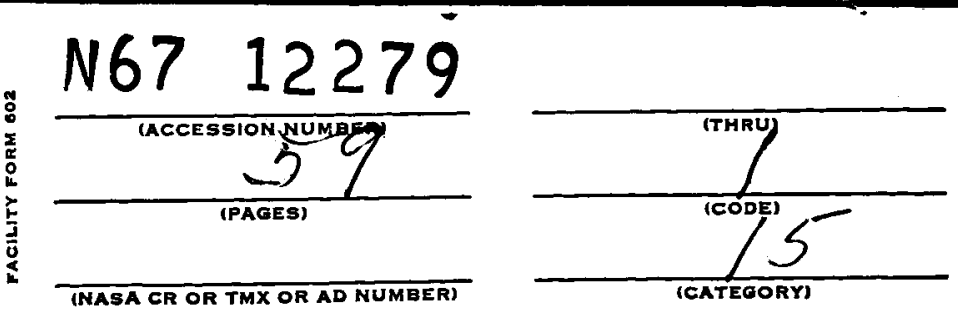


\section{NASA SP-5026}

\section{BRAZING AND \\ BRAZING ALLOYS}

\section{A BIBLIOGRAPHY}

Material for this bibliography was selected by Center for Application of Science and Technology

Wayne State University 


\section{NOTICE}

This document was prepared under the sponsorship of the National Aeronautics and Space Administration. Neither the United States Government nor any person acting on behalf of the United States Government assumes any liability resulting from the use of the information contained in this document, or warrants that such use will be free from privately owned rights. 


\section{FOREWORD}

The Administrator of the National Aeronautics and Space Administration has established a technology utilization program for "the rapid dissemination of information....on technological developments.... which appear to be useful for general industrial application." From a variety of sources, including NASA Research Centers and NASA contractors, space-related technology is collected and screened; and that which has potential industrial use is made generally available. Information from the nation's space program is thus made available to American industry, including the latest developments in materials, management systems, processes, products, techniques and analytical and design procedures.

This publication is a part of a series of bibliographic publications intended to serve both scientific and technical personnel and the libraries and librarians who support them.

George Howick, Director Technology Utilization Division

National Aeronautics and Space Administration 


\section{ORDERING INFORMATION AND ORDER BLANKS}

Documents, Reprints and/or Micro-images should be obtained from the indicated sources.

A-Documents and documents provided with the notations "OTS" or "CFSTI" and indicating a price should be ordered from:

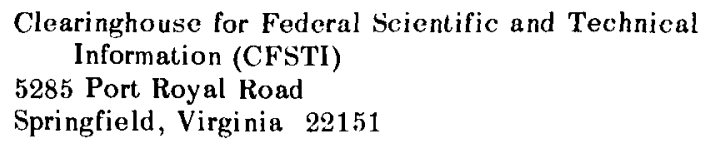

and checks should be made payable to: "National Bureau of Standards, CFSTI."

A-Documents provided with the notation "G.P.O." and indicating a price should be ordered from:

Superintendent of Documents

U.S. Government Printing Office

Washington, D.C. 20402

and checks should be made payable to the "Superintendent of Documents." 


\section{CONTENTS}

page

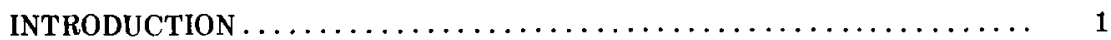

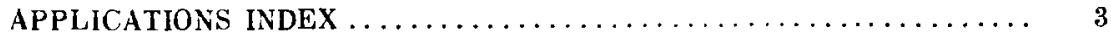
ABSTRACTS

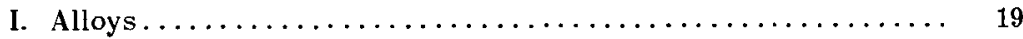

II. Basic \& Technical Papers...................... 23

III. Fabrication Methods . . . . . . . . . . . . . . . . 31

IV. Methods \& Methods Development ................... 39

V. Testing \& Evaluation $\ldots \ldots \ldots \ldots \ldots \ldots \ldots \ldots \ldots \ldots \ldots \ldots \ldots \ldots \ldots \ldots$ 


\section{INTRODUCTION}

This bibliography has been prepared as an aid in identifying and appraising that literature on Brazing and Brazing Alloys which is currently contained in NASA Information Systems and made available through various sources as indicated in the abstracts. The bibliography is arranged to permit rapid identification of its contents. The cited literature is subdivided into sections dealing with Alloys, Basic and Technical Papers, Fabrication Mothods, Methods and Methods Development, and Testing and Evaluation. Additionally, an "Applications Index" beginning on page 3, thoroughly characterizes the content of each citation under as many as six or more headings. The roman numerals in parentheses following the abstract number indicate the section in which the abstract may be found.

Material presented in this bibliography has been selected from a retrospective search of NASA's Scientific and Technical Information Division's data bank and was carefully reviewed to include only those items which have specific industrial application. Following are several significant representative entries:

N62-17269 DEVELOPMENT OF PARTIALLY VOLATILE BRAZING FILLER ALLOYS FOR HIGH-TEMPERATURE APPLICATION AND RESISTANCE TO OXIDATION.

N63-15878 DEVELOPMENT OF LOW TEMPERATURE BRAZING ALLOYS FOR TITANIUM HONEYCOMB SANDWICH MATERIALS.

N64-22683 STUDY OF LOW MELT BRAZING ALLOYS.

A63-11989 WELDING AND BRAZING OF SPACE AGE MATERIALS.

H. C. Emerson (Rohr Corp., Chula Vista, Calif.)

N63-22637 APPLIED RESEARCH AND DEVELOPMENT WORK ON FAMILIES OF BRAZED AND WELDED FITTINGS FOR ROCKET PROPULSION FLUID SYSTEMS. PHASE I: MATERIAL SELECTION, PROCESS DEVELOPMENT, AND PRELIMINARY DESIGN.

M. H. Weisman, G. Martin, W. D. Padian, S. Salmassy, T. Fan, et al.

N63-22786 THE INVESTIGATION OF EXOTHERMIC BRAZING OF REFRACTORY ALLOYS.

A63-10926 BRAZING BERYLLIUM FOR AEROSPACE APPLICATIONS.

C. L. Cline and R. A. O'Neill (Lockheed Aircraft Corp., Lockheed Missiles and Space Co., Sunnyvale, Calif.)

A63-11994 JOINING OF REFRACTORY METALS FOR SPACE POWER APPLICATIONS.

G. M. Slaughter, C. W. Fox, and R. G. Gilliland (Oak Ridge National Laboratory, Metallurgy Div., Oak Ridge, Tenn.)

N65-14657 DEVELOPMENT OF HIGH STRENGTH, BRAZED ALUMINUM, HONEYCOMB SANDWICH COMPOSITES ADAPTABLE FOR BOTH ELEVATED AND CRYOGENIC TEMPERATURE AP. LICATIONS. 
S. D. Elrod and J. T. Stacy (Boeing Co., Aero-Space Div., Materials and Processes Section, Seattle, Wash.)

A64-11145 THE BRAZING OF TITANIUM TO ALUMINUM.

F. Bollenrath and G. Metzger (Rheinisch-Westfalische Technische Hochschule, Institut for Werkstoffkunde, Aachen, Germany)

A65-13470 PRACTICAL ASPECTS OF BRAZING BERYLLIUM METAL. E. F. Weismantel and K. C. Taber (Beryllium Corp., Reading, Pa.)

N64-10034 CLADDING BETWEEN ALPAX AND SINTERED Al-Al $\mathrm{O}_{3}$, APPLICATION TO BRAZING OF PIECES OF SINTERED Al-Al ${ }_{2} \mathrm{O}_{3}$. (EXAMEN DE PLACAGES ALPAX/FRITTE Al-Al ${ }_{2} \mathrm{O}_{3}$ APPLICATION AU BRASAGE DE PIECES EN FRITTE Al-Al ${ }_{2} \mathrm{O}_{3}$ )

J. Herenquel and C. Leymonie (TRF FIMETAUX).

N65-12196 TANTALUM AND MOLYBDENUM BRAZING TECHNIQUES.

A. H. Freedman, L. H. Stone, and E. B. Mikus.

A66-10973 IN SITU TESTING OF BRAZED HYDRAULIC PIPE JOINTS IN AIRCRAFT.

J. Boraston (British Aireraft Corp. (Operating), Ltd., Filton Div., Bristol, England and B. Harris-Maddox (Ultrasonoscope Co., Ltd., London, England)

N65-23646 IRRADIATION DAMAGE TO CERAMICS, METALLIC-CERAMIC,
BONDS, AND BRAZING ALLOYS. Alton J. Patrick.

This bibliography is one of a sories of Technology Utilization Bibliographies. Their purpose is to provide Business and Industry with summarizing information on space technology literature. Information is presented in a convenient format and it is anticipated that the bibliographies will stimulate further inquiry, consultation and requests for reprinted material.

This volume is based upon an earlier, unpublished bibliography selected by the Center for Application of Science and Technology at Wayne State University. The present material was obtained through a system-search at the Knowledge Availability Systems Center of the University of Pittsburgh.

The published material is a selection from the wealth of information and new technology in the collections of the National Aeronautics and Space Administration. The selection has been directed toward an audience with limited research and development capability, and the emphasis is on application of new technology. Untranslated foreign language material has been generally omitted except for a few items that were considered important for a complete picture of current technology.

Directions for ordering the complete document are provided on page iv. 


\section{APPLICATIONS INDEX}

A

Abrasive Brazing:

SAP: N64-18979(IV)*

Aerospace Applications:

brazing of beryllium for: A63-10926(III)

review of advanced techniques: A63-25757 (II)

\section{Airframe Structure:}

braze evaluation: N64-11925(III)

\section{Alumina Ceramics:}

brazed joints with columbium alloy: N65-32767(IV)

\section{Aluminum:}

foam, brazing to SAP-1 material: N62-14327(IV)

friction welding, stainless steel: A66-15002(III)

fusion welding, stainless steel: A66-15002(III)

honeycomb panels, high temperature and cryogenic applications: N65-14657(III)

interaction of brazes with: N64-10805(I)

joining to stainless steel: A66-15002(III)

soldering to steel: N65-20202(IV)

solid state diffusion bonding, stainless steel: A66-15002(III)

steel, brazing of: N65-20201(IV)

Aluminum Fittings: N63-22637(II)

Aluminum 0xide:

dense, brazed wire endcaps: N64-28621(III)

sintered, cladding and brazing of: N64-10034(IV)

\section{Aluminum Solder:}

brazing of SAP: N64-10750(IV)

Antennas:

refractory alloy, fabrication of high temperature: A65-11571(III)

Assembly:

controlled atmosphere brazing: A64-24592(II)

\section{Atmospheres:}

controlled, furnance brazing, equipment: N65-10020(IV)

*Roman numerals in parentheses indicate section in which abstract appears. 
Brazing and Brazing Alloys

Atmospheres: (Continued)

controlled atmosphere brazing: A64-24592(II)

fluxes, stainless steel, heat resistant alloys: N65-15680(IV)

Atmospheric Evaluation:

brazed titanium: N64-16635(V)

Base Material:

dissolution during soldering: N65-20203(II)

interaction with brazing alloy: N65-20203(II)

Beryllium:

beryllium alloys, bjbliography: N64-20547(II)

brazing:

alloys for: A63-11994(III)

for aerospace applications: A63-10926(III)

of: A65-13470(IV), N64-27230(IV)

electron beam brazing of: N64-31095(IV)

\section{Bibliography:}

beryllium and beryllium alloys, brazing of: $\mathrm{N} 64-20547$ (II)

Bimetals:

applications for brazing titanium alloys: N65-23382(IV)

\section{Bonding:}

thermoelectric: N65-29743(IV), N65-29747(IV), N65-29779(IV)

\section{Boron Alloys:}

filler alloys: A64-10082(I)

Braze Evaluation Method:

molybdenum alloy, stainless steel braze: N63-21707(III)

Braze Fractures:

causes of: N64-27635(II)

\section{Braze Zone Blisters:}

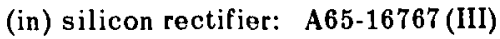

\section{Brazed Fittings:}

propulsion fluid systems, aluminum, stainless steels, nickel alloys: N63-22637 (II)

\section{Brazes:}

interaction of, (with) SAP and aluminum: N64-10805(I)

\section{Brazing Alloy:}

base material interaction: N65-20201(IV)

boron alloys: A64-10082(I)

columbium, ternary alloys, binary alloys: A64-26694(III)

Dynabraze B, composition optimization: N63-20957(I) 
Brazing Alloy: (Continued)

electron beam brazing, beryllium: N64-31095(IV)

evaluation of, induction brazing: A65-15374(II)

foil reducibility: N65-14657 (III)

(for) René 41, Mn-Ni-Co-B-alloy: A63-23743(III)

high strength steels: N64-11267(II)

high temperature tubing applications: N63.19265(I)

interaction with base material: N65-20203(II)

irradiation damage to: N65-23646(V)

low melt, study of: N64-22683(I)

low temperature, titanium honeycomb materials: N63-15878(I)

nickel alloy honeycomb sandwich: N64-17131(I)

palladium, applications of: A65-12250(I)

reactive, platinum, boron: N62-12073(IV), N62-12233(IV), N62-12646(IV)

silver-copper-lithium, beryllium brazing: A63-10926 (III)

stainless steel, heat resistant alloys: N65-15680(IV)

stainless steel honeycomb, palladium alloys: A63-23742(I)

titanium-to-aluminum: A64-11145(IV)

Brazing Alloy Composition:

various, meeting report: N64-28514(II)

Brazing Filler:

volatile, high temperature application, oxidation resistance: N62-17269(I)

Brazing Fixtures:

controlled atmosphere brazing: A64-24592(II)

Brazing Method:

nonferrous metals, diffusion brazing: N65-11318(IV)

Brazing 0perations:

shortcomings of some: N66-12730(II)

Brazing Problems:

evaluation of: N66-12731(II)

Brazing Preparation:

stainless steel, heat resistant alloy brazes: N65-15680(IV)

Butt-Brazing:

beryllium: N64-27230(IV)

C

Carbon Steel:

brazing alloy composition: N64-28514(II)

Ceramic:

brazed joints with columbium alloy: N65-32767 (IV)

Ceramic-Metal Joint:

palladium brazing alloys for: A65-12250(I) 
Brazing and Brazing Alloys

Cladding:

(and) brazing, sintered aluminum oxide: N64-10034(IV)

\section{Columbium:}

brazing alloys for: A63-11994(III)

brazing of: A63-20775(IV), N62-16923(IV)

(D36), honeycomb structures, brazing of: A64-26694(III)

unalloyed, exothermic brazing of: N63-22786(II)

Columbium Alloy:

brazed joints with alumina ceramics: N65-32767(IV)

Columbium Brazing Alloy:

Ti-Cr-V ternary, Ti-Cr-binary alloys: A64-26694(III)

Columbium Panels:

brazed sandwich, development of: N64-16450(III)

Composition Optimization:

Dynabraze B, brazing alloy: N63-20957 (I)

Controlled Atmosphere:

furnace brazing, equipment: N65-10020(IV)

Controlled Atmosphere Brazing:

various aspects of: A64-24592(II)

Copper to Brass:

induction brazing: A65-15374(II)

Cryogenic Applications:

aluminum honeycomb panels, high temperature applications: N65-14657 (111)

\section{Cutting Tool:}

hard alloy brazed tips: N65-27534(III)

\section{Damage:}

irradiation, to brazing alloys: N65-23646(V)

\section{Diffusion:}

activated tungsten, refractory metals: N63-13980(IV)

\section{Diffusion Bonding:}

solid state, aluminum, stainless steel: A66-15002(III)

titanium alloys, to various metals: A66-15001(IV)

tungsten: A63-10452(II)

\section{Diffusion Brazing:}

non-ferrous metals, methods: N65-11318(IV)

Diffusion Processes: N64-27635(II)

brazing rhenium-coated titanium: N64-21189(II)

investigation of, in titanium alloys: N65-20201 (IV), N65-20204(II) 
Diffusion-Sink:

system, brazing tantalum, molybdenum: N65-35765(IV)

\section{Diffusion-Sink Brazing:}

refractory metals, molybdenum, tantalum: N65-12196(IV)

\section{Dip Brazing:}

salt bath, aluminum, stainless steel: A66-15002(III)

SAP: N64-18979(IV)

Dissimilar Metals Joint:

palladium alloys for: A65-12250(I)

\section{Dynabraze B:}

brazing alloy, composition optimization: $\mathrm{N} 63-20957$ (I)

Dynamics of Wetting:

in brazing: N63-12304(II)

D-36 (Cb-Ti, Zr)-Alloy:

brazing alloys for, honeycomb: A63-15334(I)

E

\section{Electric Motor Rotors:}

short-circuited, brazing of: N65-15675(III)

\section{Electron Beam Brazing:}

beryllium: N64-31095(IV)

\section{Equipment:}

controlled atmospheres, furnace brazing: N65-10020(IV)

description, brazing rotors for electric motors: N65-15675(III)

review, tooling, facilities, techniques: A63-11989(II)

\section{Evaluation:}

atmospheric, brazed titanium: N64-16635(V)

braze, molybdenum alloy, stainless steel braze: N63-21707 (III)

brazed airframe structure: N64-11925 (III)

brazed honeycomb sandwich: N64-22575(V)

SAP brazed joint: N64-18979(IV)

structural repair, brazed honeycomb: N64-12648(III)

Exothermic Brazing:

concepts, considerations: A65-11573(IV)

refractory alloys: N63-22786(II)

investigation of: N64-16840(IV)

\section{$\mathbf{F}$}

\section{Fabrication:}

detail, controlled atmosphere brazing: A64-24592(II)

high temperature refractory alloy antennas: A65-11571(III) 
Brazing and Brazing Alloys

Facilities:

review, tooling, equipment, techniques: A63-11989(II)

Failure Mechanism: N65-35114(IV)

Fiber Metal Resistance Brazing:

molybdenum sheet, feasibility study: N62-12946(II)

Filler Alloys:

boron alloys: A64-10082(I)

Fittings:

brazed, propulsion fluid systems, aluminum, stainless steel, nickel alloys: N63-22637 (II)

Flame Brazing (Gas):

various solders: N64-18977 (IV)

Fluxes:

gas media, stainless steel, heat resistant alloys: N65-15680(IV)

Foil:

refractory metals, t-joint brazements: N65-10898(IV)

Foil Reducibility:

brazing alloys for aluminum: N65-14657(III)

Fractures:

causes of: N64-27635(II)

\section{Friction Welding:}

aluminum, stainless steel: A66-15002(III)

Furnace Brazing:

controlled atmospheres, equipment: N65-10020(IV)

graphite fixtures: A63-10452(II)

SAP: N64-18979(IV)

Fusion Welding:

aluminum, stainless steel: A66-15002(III)

G

Gas-Flame Brazing:

various solders: N64-18977 (IV)

Graphite Fixtures:

hydrogen brazing, methane equilibrium: A63-10452(II)

H

Hard Alloy Tips:

brazed on cutting tool: N65-27534(III)

8 
Heat Exchanger Tubes:

mechanized brazing of: $\mathrm{N} 63-19873$ (III)

Heat Resistant Alloys:

stainless steels, brazing of: N65-15680(IV)

High Melting Palladium Brazing Alloy:

applications of: A65-12250(I)

High Speed Brazing: A63-11989(II)

High Strength Steel:

brazing of: N64-11267(II)

High Temperature Applications:

aluminum honeycomb panels, cryogenic applications: N65-14657(III)

tubing, brazing alloys: N63-19265(I)

volatile brazing filler, oxidation resistance: N62-17269(I)

High Temperature Brazing:

refractory metals: A64-24499(IV)

High Temperature Service:

tungsten, low temperature brazing: N62-12073(IV), N62-12233 (IV), N62-12646 (IV)

High Temperature Solders:

brazing with: N64-10354(II)

High Temperature Structures: A63-25774(II)

Honeycomb:

brazed, structural repair evaluation: N64-12648(III)

René 41 nickel alloy, brazing of: A64-15276(III)

\section{Honeycomb Materials:}

titanium, low temperature brazing alloys: N63-15878(I)

Honeycomb Panel:

aluminum, high temperature and cryogenic applications: N65-14657 (III)

refractory alloys, brazing alloys for: A63-15334(I)

refractory metals foils: N65-10898(IV)

stainless steel, brazing of: A63-11839(III)

Honeycomb Sandwich:

evaluation of: N64-22575(V)

nickel alloy, brazing alloys: N64-17131(I)

panels, refractory alloys, quartz lamp brazing: N63-11011(IV)

René 41 (nickel alloy) brazing of: A63-23743(III)

Honeycomb Structures:

columbium (D36), brazing of: A64-26694(III)

Hydrogen Brazing:

graphite fixtures, methane equilibrium: A63-10452(II) 
Brazing and Brazing Alloys

Inconel 718:

brazing alloys, honeycomb sandwich: N64-17131(I)

Induction Brazing:

description and advantages of: A65-15374(II)

inert atmosphere: A65-11571(III)

Inert Atmosphere:

induction brazing: A65-11571(III)

\section{Interaction:}

brazing alloy-base material: N65-20201(IV), N65-20203(II)

of brazes, (with) SAP and aluminum: N64-10805(I)

Irradiation Damage:

to brazing alloys: N65-23646(V)

Joint:

aircraft pipe, testing of: A66-10973(III)

evaluation of brazed SAP: N64-18979 (IV)

nondestructive testing of: N65-17131(V)

pipe, brazing of: A64-16014(III)

sink, precoating: N65-35765(IV)

$\mathrm{X}$-ray examination of: N66-13905(V)

Joint Design:

stainless steel, heat resistant alloys: N65-15680(IV)

Low-Melt Brazing Alloys:

study of: N64-22683(I)

Low Temperature Brazing:

tungsten, for high temperature service: N62-12073(IV), N62-12233(IV), N62-12646 (IV)

Low Temperature Brazing Alloys:

titanium honeycomb materials: N63-15878(I)

M

Manganese-Nickel Brazing Alloy:

high strength steols: N64-11267(II)

\section{Materials:}

controlled temporature brazing: A64-24592(II) 
Mechanized Brazing:

heat exchanger tubes: N63-19873(III)

Meeting Report: N64-28514(II)

Metallizing:

alumina ceramic for brazing: N65-32767(IV)

Methane Equilibrium:

hydrogen brazing, graphite fixtures: A63-10452(II)

Methods:

stainless steels, heat resistant alloys: N65-15680(IV)

Molybdenum:

brazing of: A63-20775(IV), N62-16923(IV)

brazing techniques:

diffusion-sink brazing: N65-12196(IV)

diffusion-sink system: N65-35765(IV)

unalloyed, exothermic brazing: N63-22786(II)

Molybdenum Alloy (PH 15-7 Mo):

stainless steel (17-7 PH), braze evaluation: N63-21707(III)

Molybdenum Sheet:

fiber metal resistance brazing, feasibility study: N62-12946(II)

Molybdenum-Titanium-Zirconium Alloy:

fiber metal resistance brazing: N62-12946(II)

N

Nickel Alloys:

brazing of titanium alloys with: N65-23382(IV)

(Inconel 718) brazing alloys, honeycomb sandwich: N64-17131(I)

(René 41):

brazing of honeycomb: A64-15276(III)

fittings: N63-22637 (II)

honeycomb sandwich, brazing of: A63-23743(III)

Nickel Base Alloys:

joining of: N63-12583(IV)

Nickel-Base Braze Alloys: N64-10334 (IV)

Nickel-Boron-Silicon Brazing Alloy:

high strength steels: N64-11267(II)

Nickel-Chrome-Aluminum:

brazing alloys, high temperature tubing: N63-19265(I)

Nickel-Chromium-Boron-Silicon Brazing Alloy:

high strength steels: N64-11267(II) 
Brazing and Brazing Alloys

Nickel-Silicon-Boron:

brazing alloy: N63-19265(I)

Nimonic 90:

induction brazing of: A65-15374(II)

Nonferrous Metals:

diffusion brazing methods: N65-11318 (IV)

0

Oxidation Resistant Filler:

volatile brazing filler, high temperature application: N62-17269(I)

$\mathbf{P}$

Palladium:

brazing alloys, applications of: A65-12250(I)

filler metals, brazing alloys, stainless steel honeycomb: A63-23742(I)

Pipe:

aircraft pipe joints, testing of: A66-10973(III)

thin-walled, brazing of: N65-15682(III)

Pipe Joints:

brazing of: A64-16014(III)

Plastic Deformation:

thin joints, silver, tubular steel: N63-13298(II)

Platinum-Boron:

brazing alloy, tungsten: N62-12233(IV), N62-12646(IV)

reactive braze system: $\mathrm{N} 62-12073$ (IV), N62-12233(IV), N62-12646(IV)

Post-Braze Operations:

controlled atmosphere brazing: A64-24592(II)

Power Wire Endseals:

brazing of: N64-28621(III)

Precipitation Hardening Stainless Steels:

brazing alloy and process: A63-11977(III)

Precoating:

sink braze joint: N65-35765(IV)

\section{Preparation:}

controlled atmosphere brazing: A64-24592(II)

stainless steels, heat resistant alloy brazes: N65-15680(IV)

Pressure Application:

controlled atmosphere brazing: A64-24592(II)

Problems:

brazing, titanium alloys: N64-11271(IV) 
Quality:

discussion of brazing: N66-12731(II)

Quality Control:

controlled atmosphere brazing: A64-24592(II)

need of: N66-12730(II)

stainless steel, heat resistant alloy brazements: N65-15680(IV)

Quartz Lamp Brazing:

radiant heat, refractory honeycomb panels: N63-11011 (IV)

$\mathbf{R}$

Radiant Heat Brazing:

quartz lamp, refractory honeycomb panels: N63-11011 (IV)

\section{Rapid Heating:}

salt baths, titanium brazing in: N63-22966(IV)

Reactive Braze System:

platinum-boron, development of: N62-12073(IV), N62-12233(IV), N62-12646 (IV)

Refractory Alloy:

antennas, fabrication of high temperature: A65-11571(III)

exothermic brazing: N63-22786(II), N64-16840(IV)

honeycomb sandwich panels, quartz lamp brazing: N63-11011(IV)

Refractory Metal:

brazed sandwich, development of: N64-16450(III)

brazing, brazing alloys for: A63-11994(III)

brazing techniques, diffusion-sink brazing: N65-12196(IV)

foils, t-joint brazements: N65-10898(IV)

high temperature brazing of: A64-24499 (IV)

review, brazing of: A63-20775(IV)

tungsten, activated tungsten diffusion: N63-13980(IV)

Refractory Metal Sandwich:

braze alloy studies: A63-15334(I)

René 41 (Nickel Alloy):

honeycomb, brazing of: A64-15276(III)

honeycomb sandwich, brazing of: A63-23743 (III)

\section{Resistance Brazing:}

fiber metal, molybdenum sheet: N62-12946(II)

SAP: N64-18979(IV)

\section{Resistance Butt Brazing:}

beryllium: N64-27230(IV) 


\section{Brazing and Brazing Alloys}

Review: N65-21370(II)

advanced techniques, aerospace applications: A63-25757(II)

brazing, diffusion bonding, titanium alloys: A66-15001(IV)

brazing of refractory metals: A63-20775(IV)

equipment, tooling, facilities, techniques: A63-11989 (II)

selected shop techniques: N65-34426(III)

\section{Rhenium Coating:}

titanium, diffusion processes, brazing of: N64-21189(II)

\section{Rotors:}

electric motors, brazing of: N65-15675(III)

\section{S}

Salt Bath:

dip brazing, aluminum, stainless steel: A66-15002(III)

rapid heating, brazing titanium: N63-22966(IV)

Sandwich:

brazed, refractory metals, development of: N64-16450(III)

SAP:

brazing of: N64-10750(IV)

joint evaluation: N64-18979(IV)

brazing to foam aluminum: N62-14327 (IV)

interaction of brazes with: N64-10805(I)

Silicon Rectifier:

braze zone blister study: A65-16767(III)

Silver-Aluminum:

brazing alloy, titanium-to-aluminum: A64-11145(IV)

Silver-Aluminum-Manganese:

brazing alloy (Dynabraze B): N63-20957 (I)

Silver-Copper-Germanium:

brazing alloys, titanium honeycomb: N63-15878(I)

Silver-Copper-Lithium:

brazing alloy:

for beryllium: A63-10926(III)

high strength steels: N64-11267(II)

Silver-Copper-Palladium Brazing Alloys:

applications of: A65-12250(I)

Silver-Copper-Zinc:

brazing alloys, titanium honeycomb: N63-15878(I)

Silver Joints:

tubular steel, plastic deformation: N63-13298(II) 
Silver-Palladium Brazing Alloys:

applications of: A65-12250(I)

high strength steels: N64-11267(II)

Sintered Aluminum Oxide:

cladding and brazing of: N64-10034(IV)

Sintered Aluminum Powder: See SAP

\section{Solders:}

high temperature, brazing with: N64-10354(II)

\section{Solid State Diffusion Bonding:}

aluminum, stainless steel: A66-15002 (III)

\section{Space-Age Materials (Unspecified):}

exothermic brazing of: A65-11573(IV)

\section{Spot Brazing:}

beryllium: N64-27230(IV)

\section{Stainless Steel:}

friction welding, aluminum: A66-15002(III)

fusion welding, aluminum: A66-15002 (III)

heat resistant alloys, brazing of: N65-15680 (IV)

honeycomb panels:

brazing of: A63-11839(III)

structural repair of: $\mathrm{N} 64-12648$ (III)

induction brazing of: A65-15374(II)

joining to aluminum: A66-15002(III)

molybdenum alloy, braze evaluation: N63-21707(III)

precipitation hardening, brazing alloy, process: A63-11977 (III)

solid state diffusion bonding, aluminum: A66-15002(III)

Stainless Steel Fittings: N63-22637 (II)

Stainless Steel Honeycomb:

palladium-containing brazing alloys: A63-23742(I)

Steel:

brazing of, to aluminum: N65-20201(IV)

high strength, brazing of: N64-11267(II)

soldering to aluminum: N65-20202(IV)

tubular, thin silver joints, plastic deformation: N63-13298(II)

\section{Steel Strip:}

brazing of: N64-11737(III)

Strip:

steel, brazing method: N64-11737(III)

\section{Structures:}

high temperature: A63-25774(II) 
Brazing and Brazing Alloys.

Tantalum:

brazing of: A63-20775(IV), N62-16923(IV)

brazing techniques:

diffusion-sink brazing: N65-12196(IV)

diffusion-sink system: N65-35765 (IV)

unalloyed, exothermic brazing of: N63-22786(II)

Techniques:

review, facilities, tooling, equipment: A63-11989(II)

Temperatures:

service, high (above $1000^{\circ} \mathrm{F}$ ): A63-10926(III)

Testing:

aircraft pipe joints: A66-10973(III)

nondestructive, brazed joints: N65-17131(V)

$\mathrm{X}$-ray examination, braze joints: N66-13905(V)

Thermionic Converter:

brazing methods for: N65-35354(III)

Thermoelectric Bonding: N65-29743(IV), N65-29747(IV), N65-29779(IV), $\mathrm{N} 65 \cdot 35114$ (IV)

Thin Joints:

silver, tubular steel, plastic deformation: N63-13298(II)

Thin-Walled Pipes:

brazing of: N65-15682(III)

Ti-Cr Binary Alloys:

columbium brazing: A64-26694(III)

Ti-Cr-V Ternary Brazing Alloys:

columbium brazing: A64-26694(III)

Titanium:

brazed, atmospheric evaluation: N64-16635(V)

brazing and electroslag welding of: N65-11678(IV)

honeycomb materials, low temperature brazing alloys: N63-15878(I)

investigations of diffusion processes: N65-20204(II)

rhenium coated, diffusion processes in brazing of: N64-21189(II)

Titanium Alloy:

brazing, diffusion bonding to various metals: A66-15001(IV)

brazing of with nickel alloys: N65-23382(IV)

diffusion processes, investigation of: N65-20201(IV)

(OT4), brazing of foam aluminum to: N62-14327 (IV)

problems of brazing of: N64-11271(IV)

rapid heating, salt baths, brazing in: N63-22966(IV)

Titanium to Aluminum:

brazing of: A64-11145(IV)

16 


\section{T-Joint Brazements:}

refractory metals foils: N65-10898(IV)

Tool:

cutting, brazed hard alloy pipes: N65-27534(III)

Tooling:

review, equipment, facilities, techniques: A63-11989(II)

Tube:

heat exchanger, mechanized brazing of: N63-19873(III)

Tubular Steel:

thin silver joints, plastic deformation: N63-13298(II)

Tungsten:

activated tungsten diffusion, refractory metals: N63-13980(IV)

brazing alloy, platinum-boron alloy: N62-12233(IV), N62-12646(IV)

brazing of: A63-20775(IV), N62-16923(IV)

diffusion bonding of: A63-10452(II)

low temperature brazing for high temperature service: N62-12073(IV), N62-12233(IV), N62-12646(IV)

unalloyed, exothermic brazing: N63-22786(II)

TZM (Mo-Ti-Zr)-Alloy:

brazing alloys for, honeycomb: A63-15334(1)

exothermic brazing: N63-22786(II)

$\mathbf{U}$

Ultrasonic Scanner:

testing aircraft pipe joints: A66-10973(III)

V

Vacuum Brazing:

alumina wire endcaps: N64-28621(III)

Vacuum Butt Brazing:

beryllium: N64-27230(IV)

Volatile Brazing Filler:

high temperature application, oxidation resistance: N62-17269(I)

W

Wetting:

dynamics of, in brazing: N63-12304(II)

Wire Endseals: N64-28621(III) 
Brazing and Brazing Alloys

$$
\text { X }
$$

X-Ray Examination:

braze joints: N66-13905(V)

Zinc Solder:

brazing of SAP: N64-10750(IV) 


\section{I-ALLOYS}

A63-15334

\section{BRAZE ALLOY STUDIES FOR REFRACTORY METAL SANDWICH STRUCTURES.}

J. W. McCown, C. R. Wilks, and L. J. Gagola (Martin-Marietta Corp., Space Systems Div., Baltimore, Md.)

Society of Automolive Engineers-American Society of Naval Engineers, National Aero-Nautical Meeting, Washington, D.C., Apr. 8-11, 1963, Paper 676C. 10 pp.

This is a review of studies to develop vacuum brazing procedures for fabricating D-36 (Cb-10\% Ti-5\% Zr) columbium and TZM (Mo-0.5\% Ti-0.07\% Zr) molybdenum honeycomb sandwich structures. Braze-alloy flow temperatures range from $1,800^{\circ}$ to $3,300^{\circ} \mathrm{F}$. Higher remelt temperature braze alloy systems, as well as conventional brazing alloys, are investigated. The higher temperature remelt systems show promise but require additional development. Honeycomb sandwich panels which simulate application on an aerospace vehicle, either as hot monocoque structure or as modular heat shields for a double-walled structural concept, are fabricated for structural and thermal testing.

A63-23742

\section{NEW ERA BRAZING TURNS TO FILLER METALS WITH} PALLADIUM.

A. S. Cross, Jr. (Engelhard Ind ustries, Inc., American Platinum and Silver Division, Newark, N.J.) and J. B. Adamec (International Nickel Co., Development and Research Dept., New York, N.Y.)

Welding Journal, vol. 42, Aug. 1963, pp. 645-649. 13 refs.

The author discusses the properties and applications of palladium-containing brazing alloys. The composition and melting temperatures of a number of current commercial alloys, and of some of the more promising of those under development, are tabulated. The palladium-containing brazing filler metals are seen to have exceptional wettability, good ductility, and freedom from erosive tendencies. Applications include use in supersonic aircraft to minimize heat transfer through the stainless-steel honeycomb structure.

A64-10082

A NEW LOOK AT THE BORON FILLER ALLOYS.

Forbes Miller (Wall Colmonoy Corp., Stainless Processing Div., Detroit, Mich.) Tool and Manufacturing Engineer, vol. 51, Oct. 1963, pp. 98-100.

The use of boron alloys as brazing materials. Methods of selecting brazing filler metals are described, and data are tabulated on various brazing alloys. Among the applications noted is their use in turbojet engine combustion chambers. A method for determining the shear stress in the joint of a brazed component is briefly described.

A65-12250

PALLADIUM BRAZING ALLOYS.

John B. Adamec (International Nickel Co., Inc., Development and Research Dept., New York, N.Y.) Assembly Engineering, vol. 7, Dec. 1964, pp. 35-37.

The properties and composition of brazing alloys containing from 5 to $60 \% \mathrm{Pd}$ are briefly described. These alloys are classified into three groups: the silver- 
copper-palladium series, the silver-palladium series, and the high-melting series. Applications include dissimilar-metal joints, metal-ceramic joints, extremely thin sheet-metal assemblies, and assemblies that must withstand extreme service temperature. Where low brazing temperatures are required, $68 \mathrm{Ag}-27 \mathrm{Cu}-5 \mathrm{Pd}$ alloy is recommended for its economy. For brazing nickel-base alloys with minimum erosion of the base metal, $75 \mathrm{Ag}-\mathrm{Pd} 20-\mathrm{Mn} 5$ brazing alloy is found to be particularly effective. When strength at elevated temperatures is an important requirement, $48 \mathrm{Ni}-31 \mathrm{Mn}-21 \mathrm{Pd}$ alloy is suggested. A critical factor in the resulting joint reliability is seen to be the method of brazing. For best results, it is urged that the furnace or induction-heating conditions be carefully controlled.

W.M.R.

N62-17269

DEVELOPMENT OF PARTIALLY VOLATILE BRAZING
FILLER ALLOYS FOR HIGH-TEMPERATURE APPLICA-
TION AND RESISTANCE TO OXIDATION. [Final Tech-
nical Report, Mar. 15, 1961-Mar. 14, 1962]

Nikolajs Bredzs, John F. Rudy, and Harry Schwartzbart. Wright-Patterson AFB, Ohio, Directorate of Materials and Processes, July 1962. 52 pp. 9 refs.

(Contract AF 33(616)-6882, Armour Research Foundation, Chicago, Ill.)

(WADC-TR-59-404, Part III.)

It has been shown thermodynamically and confirmed experimentally that a high-vapor-pressure constituent of a given filler metal can be volatilized in a shorter time, or at a lower temperature, or to a greater extent, if to the given filler metal are added other constituents, which have a larger free energy of solution in the given filler metal than the volatile constituent has. Specifically, it has been experimentally demonstrated that additions of aluminum, chromium, silicon, and to a lesser extent iron and germanium, increase the rate of volatilization of indium from nickel. This order of effectiveness confirms, according to available thermochemical data, the above hypothesis. In a practical sense, the effects of the joint goometry on the ability to volatilize are discussed.

Author

N63-15878 DEVELOPMENT OF LOW TEMPERATURE BRAZING

ALLOYS FOR TITANIUM HONEYCOMB SANDWICH MATE-

RIALS. [Final Report, Dec. 1, 1961-Nov. 30, 1962]

W. C. Troy. Wright-Patterson AFB, Ohio, Directorate of Materials and Processes, Jan. 1963.49 pp. 3 refs.

(Contract AF 33(616)-7249, Solar, San Diego, Calif.)

(ASD-TR-61-313, Part II.)

For brazing titanium under $1100^{\circ} \mathrm{F}$, binary information formed the basis of selecting two promising ternary al loys for development: $\mathrm{Ag}-\mathrm{Cu}-\mathrm{Ge}$ and $\mathrm{Ag}-\mathrm{Cu}-\mathrm{Sn}$. Melt and flow behavior was favorable with $\mathrm{Ag}-\mathrm{Cu}-\mathrm{Sn}$ base alloys, but work was discontinued because of excessive joint brittleness related to intermetallic films formed on the substrate. Alloys based on the Ag-Cu-Ge ternary also formed intermetallic films, but the joints had intermediate strength which justified evaluation. Average shear strength of lap joints varied from 10,750 psi for aged specimens to $11,900 \mathrm{psi}$ for specimens after brazing at $1100^{\circ} \mathrm{F}$. These marginal properties would justify only limited application of the $\mathrm{Ag}$ - $\mathrm{Cu}-\mathrm{Ge}$ base alloys.

Author

N63-19265 DEVELOPMENT OF Ni-Cr-Al ALLOYS FOR HIGH TEMPERATURE TUBING APPLICATIONS. [Third Quarterly Progress Report, Jan. 1-Mar. 31, 1963]

A. S. Bufferd. Apr. 15, 1963. 8 pp.

(NASA Contract NAS8-5085, New England Materials Lab. Inc., Medford, Mass.)

(NASA Cr-50758) OTs: $\$ 1.10 \mathrm{ph} . \$ 0.80 \mathrm{mf}$. 
Tensile test results are presented for as-received strip material aged without prior solution anneal and strip material after heliarc welding or brazing with a nickel-silicon-boron material. The welded samples were processed in two groups. One group was aged prior to welding, whereas the second group was aged after welding.

Author

N63-20957

\section{ENGINEERING RESEARCH - BRAZING ALLOY - "DYNA-} BRAZE B" - COMPOSITION - OPTIMIZATION OF

W. M. Pratt. Dec. 6, 1962. 18 pp.

(Contract AF 33(657)-11214, General Dynamics, Fort Worth, Tex.)

(ERR-FW-178)

The object of this test was to establish the optimum manganese content in Dynabraze B brazing alloy (95\% silver 5\% aluminum + manganese) to develop the best combination of crevice-corrosion resistance, lap shear strength, and brazability. The range of manganese content from $0.5 \%$ to $1.0 \%$ appears to be the best of the groups studied judging from the results of the corrosion tests and metallographic studies. However, the shear-strength values, when coupled with the results of the metallographic studies indicate the superiority of the 1\%-manganese alloy.

Author

\section{N64-10805 THE INTERACTION OF CERTAIN BRAZES WITH SAP-1 AND ADl ALUMINUM.}

V. L. Grishin. IN: Soviet Develop. in Met. Apr. 24, 1963. pp. 1-16.

Svarochnoye Proizvodstvo (Moscow), no. 12. Dec. 1962. pp. 30-34.

(See N64-10804 02-18) JPRS translation.

The interaction of zinc- and aluminum-based brazes on AD1 and SAP-1 aluminimum is examined, at brazing temperatures of $450^{\circ}$ to $610^{\circ} \mathrm{C}$. Data are given on the flow properties of the brazes on the base materials and the wetting boundary angles. Study of the degree of erosion at various temperatures and braze times indicates an optimum thickness of braze materials.

Author

N64-17131

EVALUATION OF BRAZING ALLOYS FOR THE FABRICATION OF INCONEL 718 HONEYCOMB SANDWICH PANELS.

Frank J. Coffey. Mar. 10, 1964. 33 pp.

(Contract AF 33(657)-11215, McDonnell Aircraft Corp., St. Louis, Mo.) (A469, AD-431616)

A nickel-base structural alloy, Inconel 718, has been considered for use in the fabrication of honeycomb structures capable of sustained operation at elevated temperatures. Four gold-containing braze alloys were selected for compatibility testing with Inconel 718 base metal. From the results of these tests Premabraze 128 and Premabraze 130 braze alloys appeared to be suitable for honeycombstructure brazing with Inconel 718 as base metal. No evidence was found that either of these braze alloys are susceptible to crevice corrosion. The Nicoro and Incuro 20 braze alloys were eliminated from testing because of inferior weitability and flow characteristics.

Author

N64-22683

STUDY OF LOW MELT BRAZING ALLOYS. [Final Report, Jun. 27-Oct. 30, 1963]

Julian Glasser and William E. Few. Wright-Patterson AFB, Ohio, Advanced Fabrication Tech. Branch. Feb. 1, 1964. 52 pp. refs.

Prepared for Ohio State U. Res. Foundation.

(Contract AF 33(657)-8741, Chemical and Metallurgical Research, Inc., Chat-

tanooga, Tenn.)

(ML-TDR-64-25; AD-434108) 
Brazing and Brazing Alloys

This study brings forth the possibilities of many material compositions that offer potential as low melt braze alloys for joining thin stainless steel strips at temperatures below $1,000^{\circ} \mathrm{F}$, and with shear lap joint strengths of at least 10,000 psi up to $200^{\circ} \mathrm{F}$. Low-melt brazing alloys might find application in such processes involving strip overlap and continuous braze where post heat treating and inert atmospheres may not be practical.

Author 


\section{II-BASIC \& TECHNICAL PAPERS}

A63-10452

METHANE EQUILIBRIUM IN HYDROGEN BRAZING.

M. J. Klein (Battelle Memorial Institute, Advanced Materials Technology Div., Columbus, Ohio) and K. Kinsman (Stanford University, Dept. of Materials Science, Stanford, Calif.)

Welding Journal, Research Supplement, vol. 41, Nov, 1962, pp. 503-s, 504-s. 11 refs.

In this paper is discussed the carbon-hydrogen-methane equilibrium which must be considered when hydrogen brazing in the presence of graphite. The judicious use of graphite fixtures in furnace brazing to assure optimum wetting and to avoid inconsistent brazing results is recommended.

\section{A63-11989 \\ WELDING AND BRAZING OF SPACE AGE MATERIALS.}

H. C. Emerson (Rohr Corp., Chula Vista, Calif.)

American Society of Metals, Golden Gate Conference, San Francisco, Calif., Feb. 1969 .

IN: Materials Science and Technology for Advanced Applications. Prentice-Hall, Englewood Cliffs, N. J., 1962. pp. 606-631.

This is a cursory review of the more commonplace joining processes for the space-age metals from the viewpoint of the manufacturing engineer. Metallurgical peculiarities of the materials are correlated to equipment and to tooling abilities and limitations. Recent facilities, developments, and techniques for metal joining by high-speed brazing, electron-beam, and ultrasonic welding are discussed.

A63-25757

\section{AIR FORCE MATERIALS LABORATORY PROGRAMS TO ADVANCE THE TECHNOLOGY OF JOINING FOR AERO- SPACE APPLICATIONS.}

G. E. Eichelman.

IN: American Institute of Aeronautics and Astronautics, and USAF, Vehicle Design and Propulsion Meeting, Dayton, Ohio, Nov. 4-6, 1963, Proceedings. American Institute of Aeronautics and Astronautics, N.Y., 1963, pp. 54-59. 11 refs.

The author describes briefly several advanced joining techniques developed in an effort to further technology of joining for aerospace applications, and thereby alleviate many problems inherent in design and materials. The techniques covered include brazing, diffusion bonding, and welding. ATURE STRUCTURES.

Joseph Melill (North American Aviation, Inc., Metallic Materials Laboratory, Los Angeles, Calif.)

IN: American Institute of Aeronautics and Astronautics, and USAF, Vehicle Design and Propulsion Meeting, Dayton, Ohio, Nov. 4-6, 1963, Proceedings.

American Institute of Aeronautics and Astronautics, N.Y, 1963, pp. 216-226.

The author discusses, in view of the increased aerospace-vehicle, application of heat-resistant materials, several methods of joining high-temperature 
structures, including brazing, diffusion bonding, and welding. An evaluation is given of the metallurgical characteristics of the materials to be joined.

\section{A64-24592 BONDING, BRAZING, AND WELDING.}

M. D. Davis (Beech Aircraft Corp., Wichita, Kan.), F. L. Edmondson, D. C. Mason, Francis H. Crane, A. E. Unruh (General Dynamics Corp., New York, N.Y.), Arthur N. Kugler (Air Reduction Co., Inc., Air Reduction Sales Co., New York, N.Y.), and Frank R. Swaney (Space Technology Laboratories, Inc., Redondo Beach, Calif.)

IN: Tooling for Aircraft and Missile Manufacture.

Edited by Frank W. Wilson and Walter R. Prange.

McGraw-Hill Book Co., New York, 1964, pp. 109-163.

The author describes methods of joining metallic and nonmetallic materials. In recent years the availability of strong adhesives of uniform quality and the demands of high-speed flight have caused the replacement of many components of conventional structure by adhesive-bonded components. The primary advantage of adhesive bonding is high strength. It is, however, a precise process, and handling and storage are major problems. Adhesives, honeycomb manufacture, and working procedures are described. Controlled-atmosphere brazing is discussed with reference to materials, detail fabrication, preparation, assembly, brazing fixtures, atmospheres, pressure application, post-brazo operations, and quality control. Welding processes are described, with mention of preheating, post-weld thermal treatment, design considerations, fixture design concepts, and welding fixtures.

\section{A65-15374 BRAZING WITH INDUCTION HEATING.}

E. J. Head and E. R. Perry (Delaney Gallay, Ltd., London, England). Enginecring Materials and Design, vol. 8, Jan. 1965, pp. 16-20. 6 refs.

This paper describes the scope and advantages of high-frequency induction heating for brazing in mass-production runs where continuous supervision is unnecessary. Techniques for evaluating new brazing alloys are described, and illustrations of the technique are given using a $10 \mathrm{kw}, 450 \mathrm{kc}$ induction heating unit. With this apparatus it is also possible to braze single items of simple construction where it would be uncconomical to use a large unit such as a vacuum furnace. Methods of brazing stainless steel to various materials including copper, molybdenum, platinum, and titanium are discussed and the joining of Nimonic 90 to itself and of copper to brass are described.

D.H.

\section{N62-12946 \\ FEASIBILITY STUDY OF FIBER METAL RESISTANCE BRAZING OF MOLYBDENUM SHEET.}

Robert K. Nolen and John F. Rudy. Apr. 18, 1962. 49 pp.

(Contract NOw-62-0387-d, Armour Research Foundation, Chicago, Ill.)

(ARF-2232-2, Final Rept.)

The feasibility of joining Mo-0.50 Ti-0.10 $\mathrm{Zr}$ by the fiber metal resistance brazing process has been demonstrated. Metallic fiber compositions at the faying plane concentrate the heat at the interface, reduce the current required, and thereby eliminate the two undesirable effects of temperature-electrode-base metal bonding and recrystallization of the base alloy. Increased remelt temperature of the resistance-brazed joint, due to local composition changes within the heterogeneous brazing shim during brazing has been demonstrated as feasible, but procedural improvements are indicated which should provide greater increases. Typical microstructures are presented for a number of brazing-shim compositions, and a limited amount of mechanical-property and remelt-temperature data are 
presented. A program of future effort is outlined, based on the demonstrated feasibility of the fiber metal resistance brazing process for joining refractory metals, and also based on suggested directions for improvement.

(Author Abstract)

\section{N63-12304 DYNAMICS OF WETTING IN BRAZING AND SOLDERING.}

Clyde M. Adams, Jr. July 1962. 48 pp. 1 ref.

(Contract DA-19-020-505-ORD-4917, Massachusetts Inst. of Tech., Cambridge.)

(WAL-TR-650/1)

The spreading by wetting of some liquid metals on substantially clean solid surfaces is a two-speed process with the rate of spreading related to contact angle, oxygen traces, and solid-state surface alloying.

Auihor

\section{N63-13298 PLASTIC DEFORMATION OF THIN BRAZED JOINTS IN SHEAR.}

C. W. Shaw, L. A. Shepard, and J. Wulff. Nov. 1962.53 pp. 22 refs. (Contract AF 49(638)-775, Massachusetts Inst. of Tech. Aeroelastic and Structures Research Lab., Cambridge.)

(ASRL-TR-94-3)

The plastic behavior of the more ductile phase of a two-phase material was simulated in shear tests on thin silver joints brazed in tubular steel specimens. Both the yield strength and the work hardening rate of the silver were increased by the presence of the rigid interfaces. At 10 percent strain, the flow stress of the thin joints was $1 \frac{11}{2}$ times as great as fine grained polycrystalline silver. Deformations of the silver near the steel interfaces was severely limited even at large strains, resulting in a gross strain inhomogeneity across the joint. These effects were postulated to arise from the constraint of slip by the non-yielding interfaces.

Aut hor

N63-22637
APPLIED RESEARCH AND DEVELOPMENT WORK ON FAMILIES OF BRAZED AND WELDED FITTINGS FOR ROCKET PROPULSION FLUID SYSTEMS. PHASE I: MATERIAL SELECTION, PROCESS DEVELOPMENT, AND PRELIMINARY DESIGN.

M. H. Weisman, G. Martin, W. D. Padian, S. Salmassy, T. Fan, et al. Nov. 1962. 100 pp. 27 refs.

(Contract AF 04(611)-8177, North American Aviation, Inc., Los Angeles, Calif.) (RTD-TDR-63-1027)

Recommendations are presented for lightweight brazed and welded fittings for use with rocket-propulsion fluid systems. Joining procedures and preliminary designs have been developed for induction-brazed and TIG welded fittings for tubing of AISI 347 and AM 350 stainless steels and René 41 alloy. Qualificationtest procedures and equipment have been prepared.

Author

N63-227.86

THE INVESTIGATION OF EXOTHERMIC BRAZING OF REFRACTORY ALLOYS. [Quarterly Report No. 3, May 1July 31,1963 ]

R. A. Long. Aug. 27, 1963. 18 pp.

(Contract N600(19)59237, Narmco Research and Development, San Diego, Calif.)

Shear testing of refractory alloys at elevated temperatures was performed on exothermically brazed joints of unalloyed tungsten, molybdenum, columbium, tantalum, and TZM alloy. Brittle-to-ductile transition temperature testing was performed in order to determine the effects of exothermic-reaction heat on asreceived unalloyed tungsten, molybdenum, and TZM alloy. 
N64-10354 BRAZING WITH HIGH-TEMPERATURE SOLDERS.

V. A. Gorokhov and M. I. Skripov. Nov. 19, 1963. 13 pp.

Vestnik Mashionstroyeniya (Moscow), No. 7, 1955, pp. 47-51.

(JPRS-21927: OTS-63-41172) OTS: \$0.50

This paper describes an investigation of the basic properties of compounds from Ya1T steel and KhN78T alloy brazed with three high-temperature solders (No. 1 copper base with nickel and manganese, No. 2 copper base with silicon, beryllium, zinc, and iron, and No. 3 nickel base with chromium) is discussed. Metallographic analysis indicates that there is a mutual diffusion of the solder and the base metal. With tempering of the soldered compounds, a homogeneous solid solution was formed which had good cohesion with the base metal. Intercrystalline corrosion tests indicated that compounds of Ya1T steel and KhN78T alloy( soldered with No. 3) had high resistance to intercrystalline corrosion. During prolonged heat resistance tests at $600^{\circ}$ (Ya1T) and $800^{\circ}$ (KhN78T), all samples broke down with respect to the base metals. Fatigue tests indicated that tests of soldered samples for stretching under a cyclic load give a better picture of the fatigue resistance of a soldered compound than do tests for alternate bending.

P.V.E.

\section{N64-11267 BRAZING}

F. V. Kulikov and I. R. Lekhtsiyer. Nov. 25, 1963. 9 pp.

One section and the table of contents from a book "Tverdaya Payka" (Moscow). State Power Press, 1959, pp. 33-39.

(JPRS-22033: OTS-63-41233) OTS: $\$ 0.50$

A discussion is presented of the problems encountered in brazing highstrength steel alloys. Data on the following high-temperature and corrosionresistant braze types are given: (1) silver-copper-lithium, (2) silver-palladium, (3) manganese-nickel, (4) nickel-chromium-boron-silicon, and (5) nickel-boronsilicon.

R.T.K.

N64-20547

JOINING OF BERYLLIUM AND ITS ALLOYS BY WELDING AND/OR BRAZING; AN ANNOTATED BIBLIOGRAPHY,

Jack B. Goldman, comp. Aug. 1963.37 pp. 90 refs.

(Contract NOrd-17017, Lockheed Missiles and Space Co., Sunnyvale, Calif.)

(SB-63-61)

Intense investigation has been made during the past 3 years, 1960 to 1963 , of the problem of joining beryllium and its alloys either by welding and/or brazing. This annotated bibliography is the result of the examination of printed matter for that period as found in the journal and report literature.

Author

\section{N64-21189 INVESTIGATION OF DIFFUSION PROCESSES IN BRAZ- ING RHENIUM-COATED TITANIUM.}

V. V. Bondarev and A. Ya. Shinyayev

IN: Studies in the Met. of Various Alloys, May 26, 1964, pp. 12-16. Refs.

(See N64-21187 14-18) OTS: \$1.50

The use of rhenium for the protection of titanium during high-temperature brazing was investigated. The results of mechanical and metallographic tests are given: the characteristics of the diffusion zone under various brazing conditions are presented in tabular form. The greatest mechanical strength of braze joints was obtained after brazing at $780^{\circ}$ to $820^{\circ} \mathrm{C}$ with a holding time of 15 to $20 \mathrm{~min}$. In this case a tensile strength of $19 \mathrm{~kg} / \mathrm{mm}^{2}$ was achieved with a rhenium coating $B$ to $12 \mu$ thick. At higher brazing temperatures formation of chemical compounds takes place and causes a brittle braze joint in regions of the diffusion zone as well as a sharp lowering of its strength.

R.T.K. 
N64-27635

CRITIQUE OF LITERATURE ON BRAZING.

I. Il'yevskiy. Aug. 20, 1964. 18 pp. Ref́s.

Svarochnoye Proizvodstvo (Moscow), No. 5, May 1964, pp. 36-40, 45.

(JPRS-26036: TT-64-41306) OTS: $\$ 1.00$

The causes of braze fractures in the process of brazing are discussed, and the laws of diffusion processes that occur during the reaction of braze materials with metals are examined. Various theories concerning the nature of brazing are discussed.

R.T.K.

\section{N64-28514 COLLOQUIUM ON BRAZING OF METALS AT THE XVI CONGRESS IN HELSINKI 196.3.}

Ye K. Alekseyev, 19 Aug. 1964. 6 pp.

Svarochnoye Proizvodstvo (Moscow), No. 6, 1963, pp. 42, 43.

(JPHS 25954: TT-64-41225) OTS: $\$ 1.00$

Fourteen reports and communications from various countries are presented at the colloquium on research in new brazing techniques and design peculiarities of brazing. Data are furnished in reports on brazing carbon steel with the oxyacetylene flame. The compositions of the brazing alloys were: brass (58 to $60 \%$ $\mathrm{Cu}, 40$ to $42 \% \mathrm{Zn}, \mathrm{Si}$ ) copper nickel alloy $(45$ to $47 \% \mathrm{Cu}, 43$ to $45 \% \mathrm{Zn}, 10 \% \mathrm{Ni}$, Si) silver alloy $(40 \% \mathrm{Ag}, 19 \% \mathrm{Cu}, 21 \% \mathrm{Zn}$, and $20 \% \mathrm{Cd})$. Research was also carried out on the influence on the strength of brazed joints of surface cleaning, and of the dimensions and mechanical properties of the base metal.

Author

15

N65-20203 INTERACTION OF SOLDER WITH THE MATERIAL BEING SOLDERED. 2: DISSOLUTION OF BASE METAL DURING SOLDERING.

N. F. Lashko and S. V. Lashko.

IN: Studies in the Brazing and Soldering of Metal Alloys, Mar. 2, 1965, pp. 9-19.

Refs.

Avtomat Svarka (Krev), 1963, pp. 30-35.

(See N65-20201 10-15) CFSTI: $\$ 2.00$

A study was made of the dissolution of pure metals in more readily fusible liquid metals (solders) under conditions approximating those of capillary and dip soldering. Rate of dissolution with rising temperature depends on the amount of solder and structure of the alloy that is formed in the soldered seam and the zone of diffused interaction. Formation of interlayers of incongruent chemical compounds at the contact of liquid solder with the metal being soldered decreases the rate of its dissolution near the peritectic temperature. Ways of lowering the rate of dissolution of the metal being soldered in the liquid solders are considered.

Author

15

N65-20204 INVESTIGATION OF DIFFUSION PROCESSES IN THE BRAZING OF TITANIUM ALLOYS.

A. Ya. Shinyayev and V. V. Bondarev.

IN: Studies in the Brazing and Soldering of Metal Alloys, Mar. 2, 1965, pp. 20-

24. Refs.

Tr. Inst. Met. Akad Nauk SSSR (Moscow), No. 12, 1963, pp. 121-124.

(See N65-20201 10-15) CFSTI: $\$ 2.00$

A brazing process for joining titanium to other metals is reported. The process is based on a coating of nickel-cobalt which is electroplated between the titanium and the braze. This coating has the properties of preventing oxidation of the titanium during brazing and its interaction with the braze. Temperature of the process must allow formation of a diffusion zone having a thickness of 7 to 12 


\section{Brazing and Brazing Alloys}

microns and the zone must be a solid solution of the titanium and the coating. The process was successfully applied to various titanium alloys.

J.M.D.

15

\section{N65-21370 METALS JOINING.}

R. M. Evans (Battelle Memorial Inst., Columbus, Ohio, Defense Metals Information Center)

Review of Recent Developments, Mar. 26, 1965, 4 pp. Refs.

The brazing and welding of refractory metals and the welding of high-strength steels are reviewed. Also the electrodes used for resistance-heated bonding are tabulated. Bonding processes which require only a 20 -sec cycle and which produce joints equal in strength to the base metal when coated for oxidation resistance have been developed. The development of an HY 180210 steel having a Charpy V-notch energy absorption of about $50 \mathrm{ft}-1 \mathrm{~b}$ was shown to be feasible. There is some question whether or not weldments in these alloys will be fracture tough for large flaws and high stress concentrations. It was also noted that a $\mathrm{Ni}-\mathrm{Cr}-\mathrm{Mo}-\mathrm{V}$ steel has been developed which meets most of the requirements of an HY 140 steel. When this alloy is MIG welded with a $2 \mathrm{Mn}-2 \mathrm{Ni}$ filler metal good explosion-test results are obtained. Other significant results are reviewed and evaluations tabulated.

E.E.B.

\section{N66-12730 \\ SHORTCOMINGS OF CERTAIN BRAZING OPERATIONS.}

I. I. Il'yevskiy.

IN: From the Soviet Debate on Brazing, Nov. 10, 1965, pp. 1-4. Refs.

(See N66-12729 03-15) CFSTI: $\$ 1.00$

A rebuttal to criticisms of a previously published article on brazing is presented and a list of references to support the various observations on the role of the liquid phase in the breakdown on brazed joints is included. The need for quality control of published studies on brazing is pointed out.

\section{N66-12731 \\ MORE AT'TENTION TO BRAZING PROBLEMS.}

Vu. S. Dolgov.

IN: From the Soviet Debate on Brazing, Nov. 10, 1965, pp. 5-8. Refs.

(See N66-12729 03-15) CFSTI: \$1.00

The increasing importance of brazing in many branches of technology is pointed out and the need for improved personnel training is emphasized. Publication of a fundamental brazing handbook is proposed, and recommendations on its contents include sections on: (1) interaction of the liquid brazing metal with the base metal; (2) interaction of the brazing metal and the base metal with the surrounding gas or liquid medium; (3) modern nomenclature of brazing metals and of fluxes and gas media for brazing; (4) equipment, such as soldering irons, special burners, induction coils for high frequency heating, setups for electrocontact heating, furnaces, containers, and special setups; (5) general problems of brazing technology; (6) technology of brazing various materials; and (7) brazing economics. Three mechanisms are also proposed for evaluating the influence of various brazing parameters on the weakening of the basic metal under the action of brazing metals.

N66-12732

\section{SOME REMARKS ON THE DISCUSSION OF BRAZING QUALITY.}

A. I. Gubin.

IN: From the Soviet Debate on Brazing, Nov. 10, 1965, pp. 9-11. Refs. (See N66-12729 03-15) CFSTI: $\$ 1.00$ 
Various contradictory studies on the basic theoretical problems of brazing are discussed, and the need for more refined brazing terminology is stressed. Research to determine the causes of cracks in metal during brazing is recommended, although it is stated that their appearance is possible only in the case of liquid brazing metal contact with a metal under tensile stress. It is also pointed out that (1) available experimental data show that the greater the stresses, brazing temperature, and surface activity of the liquid brazing metal, the greater the probability of crack formation and development; and (2) during the initial stage of the interaction, a layer is formed on the interface of the basic metal and brazing metal. 


\title{
III-FABRICATION METHODS
}

A63-10926 BRAZING BERYLLIUM FOR AEROSPACE APPLICATIONS. C. L. Cline and R. A. O'Neill (Lockheed Aircraft Corp., Lockheed Missiles and Space Co., Sunnyvale, Calif.)

(AWS, Annual Meeting, 43rd, Cleveland, Ohio, Apr. 9-13, 1962.)

Welding Journal, vol. 41, Dec. 1962, pp. 1098-1106. 10 refs.

This is a summary of the results of several research programs directed toward producing beryllium brazements for service at temperatures above $1,000^{\circ} \mathrm{F}$. Several silver-base alloys and brazing processes are investigated to determine the effects of the following: (1) brazing temperature, (2) time above the Ag-Be eutectic temperature, (3) heating and cooling rates, (4) braze atmosphere, and (5) preferred braze alloy and brazing process. Results indicate that time-temperature relationships have a pronounced effect on the braze if the braze temperature is above the $\mathrm{Ag}$-Be eutectic temperature $\left(1,616^{\circ} \mathrm{F}\right)$. Extended time periods above this temperature result in an increase in the formation of brittle beryllium intermetallics and porosity in the beryllium adjacent to the braze, decreasing the effective braze strength. The $\mathrm{Ag}$-Cu-Li braze alloy yields the highest elevatedtemperature strength. Both the induction process (used in conjunction with slow heating and a purified inert atmosphere) and the cold-wall-vacuum-furnace process are acceptable for high-temperature beryllium brazing.

\begin{abstract}
A63-11839 ADVANCED TECHNIQUES FOR PRODUCING STAINLESSSTEEL HONEYCOMB PANELS.

Raymond L. Gray (Aeronca Manufacturing Corp., Middletown, Ohio). Machinery, vol. 102, Jan. 2, 1963, pp. 22-26.

Problems encountered in the production of panels used as components of supersonic aircraft and missiles are discussed. The panels consist of stainless. steel honeycomb cores brazed to inner and outer stainless-steel skins. The following techniques are described: (1) electrolytic grinding on a large, numerically-controlled, skin-milling machine; (2) determination of skin dimensions by a vacuum-table method; (3) geometrical definition of the core by means of an IBM 650 computer; and (4) brazing with alloys containing sterling silver (92.5\%), copper, and small amounts of lithium. The panels are nondestructively tested for unbrazed areas, damaged cell walls, and other flaws or defects. For this purpose, an X-ray beam is directed at the panel at a slight angle from the vertical. Because of the considerable difference in density between the silver brazing alloy and the stainless steel, the former is sharply defined.
\end{abstract}

A63-11977

THE USE OF PRECIPITATION-HARDENING STAINLESS STEELS IN SUPERSONIC AIRCRAFT.

L. P. Spalding (North American Aviation, Inc., Los Angeles, Calif.)

(American Society of Metals, Golden Gate Conference, San Francisco, Calif., Feb. 1962.)

N: Materials Science and Technology for Advanced Applications. Prentice-Hall, Inc., Englewood Cliffs, N.J., 1962, pp. 309-333.

The author describes some applications of precipitation-hardening stainless steels in the North American XB-70 supersonic airplane. The metallurgical 
background is discussed for problems such as the development of a brazing alloy and process which would be compatible with optimum heat-treatment response of the steel, embrittlement of heat-treated fused welds under simulated service exposure, corrosion resistance, and crack propagation.

A63-11994

JOINING OF REFHACTORY METALS FOR SPACE POWER APPLICATIONS.

G. M. Slaughter, C. W. Fox, and R. G. Gilliland (Oak Ridge National Laboratory, Metallurgy Div., Oak Ridge, Tenn.)

(American Society of Metals, Golden Gate Conference, San Francisco, Calif., Feb. 1962.)

IN: Materials Science and Technology for Advanced Applications. Prentice-Hall, Inc., Englewood Cliffs, N.J., 1962, pp. 728-746. 13 refs.

Developments in welding, brazing, and fabrication techniques of niobium, beryllium, and their alloys are briefly discussed. Results of a metallographic survey of the specimens used in heat-treating studies are presented. Several promising brazing alloys which readily wet and flow on niobium (columbium) are tabulated.

\section{A63-23743}

\section{BRAZING RENÉ 41 HONEYCOMB SANDWICH STRUC- TURES.}

A. O. Vanaman and J. W. Greagor (Republic Aviation Corp., Farmingdale, N.Y.) (American Welding Society, Meeting, 44th Annual, Philadelphia, Pa., Apr. 22-26, 1963.)

Welding Journal, vol. 42, Aug. 1963, pp. 353s-358s.

The authors review experimental investigations to establish suitable brazing parameters for producing René 41 honeycomb sandwich test panels and simulated structural configurations for possible aerospace applications. The investigations show that high-purity argon can be used for brazing superalloys that contain titanium and aluminum, provided steps are taken to deliver "as received" argon to the retort, and provided "hot purging" techniques are employed to remove contaminating vapors from the retort, tooling aids, etc. The optimum brazing alloy for Reno' honeycomb-sandwich structures for anticipated service conditions is a $\mathrm{Mn}-\mathrm{Ni}-\mathrm{Co}-\mathrm{B}$ alloy in foil form.

\section{A64-15276 BRAZING OF THIN GAGE RENÉ 41 HONEYCOMB.}

L. H. Stone, A. H. Freedman, and E. B. Mikus (Northrop Corp., Norair Div., Materials Sciences Laboratory, Hawthorne, Calif.)

(American Welding Society, National Fall Meeting, Boston, Mass., Sept. 30-Oct. 3, 1963.)

Welding Journal, Research Supplement, vol. 42, Sept. 1963, pp. 397s-403s.

Commercial braze alloys for René 41 honeycomb brazing were studied. A

$\mathrm{Ni}-\mathrm{Cr}-\mathrm{Si}-\mathrm{Mn}$ braze alloy appeared to be the most promising and was subjected to a detailed study. This alloy was also evaluated using a "diffusion sink" concept of brazing to further reduce braze alloy-base interaction. Some of the process parameters established included: amount of braze alloy required for a given panel configuration, method of braze alloy placement, optimum brazing temperatures, and length of time at brazing temperature. The influence of the selected braze alloy, braze cycle, and postbraze heat treatments on the mechanical and metallurgical properties of the base metal as well as the braze joints was determined by short-time tensile and lap shear tests at $600^{\circ} \mathrm{F}$ and $1850^{\circ} \mathrm{F}$, and metallographic analysis. Successful transition from brazing of laboratory honeycomb specimens to full-scale 24 inch to 36 inch production panels using an infrarod quartz lamp 
process was accomplished with minor modification of the laboratory procedures. Presently planned space vehicles will require the use of moderately hot structures in certain areas and Rene 41 brazed honeycomb can fill this need.

\section{A64-16014 BRAZED PIPE JOINTS.}

D. J. Duckworth (British Aircraft Corp., Ltd., Preston Div., Mechanical Test Dept., Preston, Lancs., England) Aircraft Engineering, vol. 36, Mar. 1964, pp. 62-64.

A reliable weight-saving method is described for making permanent brazed pipe joints, in place, on high-speed aircraft. Although the process appears to be relatively simple, its success is said to depend on thorough development work in the laboratory, followed by training of production personnel in the use of the necessary specialized equipment.

\section{A64-26694 BRAZING OF COLUMBIUM D36 HONEYCOMB STRUC- TURES.}

A. H. Freedman and E. B. Mikus (Northrop Corp., Norair Div., Hawthorne, Calif.) (American Welding Society, National Fall Meeting, San Francisco, Calif., Oct. 5-8, 1964, Paper.)

Welding Journal, Research Supplement, vol. 43, Sept. 1964, pp. 385s-392s. 6 refs. Contract No. AF 33(657)-8910.

Brazing alloys were selected and procedures established for quartz-lamp brazing of thin-gage columbium D36 ( Cb-10Ti-5Zr) honeycomb structures. Honeycomb sandwich panels for structural as well as heat-shield applications were considered. Service temperature goals were $2500^{\circ} \mathrm{F}$ maximum for structural panels and $2700^{\circ} \mathrm{F}$ minimum for heat-shield panels. Braze alloys investigated for structural panels included: (1) several alloys in the Ti-Cr-V ternary system and (2) two $\mathrm{Ti}-\mathrm{Cr}$ binary alloys. Braze alloys evaluated for heat-shield applications included: (1) pure titanium, (2) Ti-13V-11Cr-3Al, (3) Ti-30V, and (4) V-20Ti. Suitability of braze alloys was based upon such factors as brazing temperature, filleting, flow and interaction behavior, high-temperature joint strength, long-time thermal stability with the base alloy and compatibility with available protective coatings for columbium alloys. Final braze alloys selected were the $\mathrm{Ti}-33 \mathrm{Cr}$ alloy for the structural panels and the $\mathrm{Ti}-13 \mathrm{~V}-11 \mathrm{Cr}-3 \mathrm{Al}$ alloy for the heat shields. Procedures were established for making the $\cdot \mathrm{Ti}-33 \mathrm{Cr}$ braze alloy by a vacuum deposition of $\mathrm{Cr}$ on 0.0015 -in.-thick pure titanium foil. Homogenization of the foil was accomplished by a short diffusion treatment incorporated into the braze cycle. This process permitted use of this braze alloy in foil form. The $\mathrm{Ti}-33 \mathrm{Cr}$ and $\mathrm{Ti}$ $13 \mathrm{~V}-11 \mathrm{Cr}-3 \mathrm{Al}$ braze alloys were evaluated for compatibility with two oxidationprotection coatings. Cyclic oxidation tests at 2350 and $2500^{\circ} \mathrm{F}$ were performed in still air. The results of this program provide a reliable brazing process for fabrication of ductile thin-gage honeycomb sandwich panels of columbium D36 for service to $2500^{\circ} \mathrm{F}$ for structural members and at least $2700^{\circ} \mathrm{F}$ for heat shields. This advance in materials technology is expected to find wide application in the aerospace industry for reusable hypervelocity re-entry vehicles. (Author) W.M.R.

\section{A65-11571 FABRICATION OF HIGH-TEMPERATURE REFRACTORY ALLOY ANTENNAS.}

S. D. Elrod and J. T. Stacy (Boeing Co., Aero-Space Div., Materials and Processes Section, Seattle, Wash.)

IN: Society of Aerospace Material and Process Engineers, National Symposium on Materials for Space Vehicle Use, 6th, Seattle, Wash., Volume 1, Nov. 18-20, 1963.

Seattle, Society of Aerospace Material and Process Engineers, 1963, $16 \mathrm{pp}$. 
The development of brazed columbium-base-alloy antennas for very-hightemperature service is briefly described. A review of antenna design and detailed fabrication sequences is presented. The brazing method is discussed in detail. Coating the subassembly and final assembly with an oxidation-resistant silicide, and the application of a pressure-tight dielectric window are discussed. The significant aspects of the work are summarized as follows: (1) selection of the inert-atmosphere-induction brazing method; (2) selection of the Ti-50w/oZr alloy for the brazing alloy, the alloy satisfying the three special criteria of low melting and high remelting temperatures, joint ductility, and the silicide-coated oxidation resistance required for this application; (3) use of accurately machined L-joints to facilitate self-jigging; (4) development of the 100-kw inert-atmosphere brazing chamber for brazing the antenna components and the heat-shield joints simultaneously; (5) orientation of the assembled antenna and heat-shield during the two coating cycles to provide a continuous, uniform, silicide-coated interior, and (6) the method of installing the dielectric window using a ceramic cement to effect a pressure-tight joint.

(Author) M.M.

\section{A65-16767}

\section{BLISTER FORMATION IN A HIGH POWER SILICON RECTIFIER UNIT.}

G. W. Coles and I. E. Cottington (General Electric Co., Ltd., Hirst Research Centre, Wembley, Middlesex, England)

Metallurgia, vol. 70, Dec. 1964, pp. 267-270.

A metallographic study was made of the braze zones of a silicon rectifier

unit. This study was made in order to determine whether the poor electrical characteristics observed on a number of the units could be related to the structure. It is shown that silicides can form during the brazing operation, and the presence of blisters in one of the braze zones is associated with the formation of a nickel silicide phase. Units containing blisters exhibited poor electrical characteristics, and alternative brazing techniques which prevented the formation of blisters resulted in units which had more uniform electrical characteristics.

(Author) A.B.K.

A66- 10973

\section{IN SITU TESTING OF BRAZED HYDRAULIC PIPE} JOINTS IN AIRCRAFT.

J. Boraston (British Aircraft Corp. (Operating), Ltd., Filton Div., Bristol, England) and B. Harris-Maddox (Ultrasonoscope Co., Ltd., London, England) Ultrasonic's, vol. 3, Oct.-Dec. 1965, pp. 175-181.

A contact scanning ultrasonic method has been developed for in-place testing of brazed joints in aircraft hydraulic systems. A description of the problems encountered using conventional methods of testing is followed by a consideration of the ultrasonic facility, its use, and the results obtained. Finally the advantages and disadvantages of the process are mentioned, and a possible future development is pointed out.

B.B.

A66-15002 \# JOINING ALUMINUM TO STAINLESS STEEL FOR SPACE VEHICLE APPLICATIONS.

Leo E. Gatzek (North American Aviation, Inc., Space and Information Systems Div., Downey, Calif.)

Society of Automotive Engineers, National Aeronautic and Space Engineering and Manufacturing Meeting, Los Angeles, Calif., Oct. 4-8, 1965, Paper 650754. 20 pp. 7 refs.

Members, $\$ 0.75$; nonmembers, $\$ 1.00$.

Techniques are reviewed for joining aluminum to stainless steel for current and advanced spacecraft applications, including process details and illustrations 
to delineate the methods of joining these dissimilar metals, and to demonstrate the integrity of aluminum-stainless steel bonds. Salt-bath dip brazing of tincoated stainless steel to aluminum, employing a standard aluminum brazing alloy, has proven feasible in all respects. It is considered that fusion welding and solid-state diffusion bonding processes may, with expanded development, also become entirely feasible. Friction welding, principally intended for high productivity, appears promising. The strength, toughness, impermeability, and thermal adaptability of the metallurgical bonds have been demonstrated in simulated launch and space-flight environments.

F.R.L.

\section{N63-19873 \\ MECHANIZED BRAZING OF HEAT-EXCHANGER TIIBES.}

S. L. Milichenko and N. Ya. Aleksandrov. Aug. 21, $1963.7 \mathrm{pp}$.

Svarochnoye Proizvodstvo (Moscow), no. 7, July 1963, pp. 28-29.

(JPRS-20734) OTS: $\$ 0.50$

A new method of mechanized brazing of heat-exchanger tubes is developed that uses a high-voltage, electric-brazing unit with a specially designed working section. In the new method, the tubes are drawn by a special mechanism through a tank containing a molten braze bath and then through a water-cooled forming die which has one end submerged in the bath. The tubes pass through the bath, are wetted by the braze, and then enter the die where the braze solidifies as the tubes move through the cooled portion of the die. A special unit was devised for this method which consists of three main assemblies, a tube-straightening device, the braze bath, and the drawing mechanism. Using this method a brazing rate of almost three meters/min was obtained which is almost 20 times faster than the oxy-acetylene method. Braze quality is good and working conditions are greatly improved.

N.E.A.

N63-21707

\section{HIGH TEMPERATURE EXPOSURE EFFECTS ON, AND EVALUATION OF, 17-7 PH AND PH 15-7 Mo BRAZED JOINTS.}

W. M. Pratt. June 6, 1962. $30 \mathrm{pp}$.

(Contract AF 33(600)-38975, General Dynamics, Fort Worth, Tex.)

(FGT-2868)

Tensile specimens of PH 15-7 Mo and 17-7 PH stainless steel were brazed with $92.5 \mathrm{Ag}-7.5 \mathrm{Cu}+2 \mathrm{Li}$ braze alloy. Control specimens, without braze alloy, were also processed through the braze cycle. The control and brazed specimens were subjected to various cycles of temperature and humidity exposure before being tensile tested. Metallographic studies of the brazed specimens were also made. Specimens subjected to one hour at $550^{\circ}, 650^{\circ}$, or $750^{\circ} \mathrm{F}$, followed by up to 96 hours of humidity exposure at room temperature did not corrode or show evidence of crevice corrosion. Specimens subjected to cycling between elevated temperatures and humidity exposures at room temperature did corrode and evidenced crevice corrosion, the amount increasing with the number of cycles of exposure and higher temperatures. Loss of strength of the base metals due to corrosion was offset by gains in strength from low-temperature precipitation hardening of the stainless steels due to the $550^{\circ} \mathrm{F}$ to $750^{\circ} \mathrm{F}$ oxidation exposures. The net results shown by the tests were a general deterioration of the braze alloy due to elevated temperature and humidity exposure, increasing with the number of exposures.

Author 
T. B. Card. Wright-Patterson AFB, Ohio. Manuf. Technol. Lab., Mar. 1963. $20 \mathrm{pp}$.

(Contract AF 33(600)-42961, Thiokol Chemical Corp., Brigham City, Utah. Wasatch Div.)

(ASD-TR-7-912 (VII); AD-401136)

Techniques have been developed for brazing steel strip to the TU-193 motorcase end rings which provide the requisite bond strengths. The techniques require varying mandrel-rotation speeds and controlling the application of heat at various points during brazing to the end rings. Work has also started on a program in which braze alloys melting in the $700^{\circ}$ to $900^{\circ} \mathrm{F}$ range will be selected and tested.

Author

N64-11925

BRAZED AIRFRAME STRUCTURE EVALUATION. [Final Report]

N. Heftl. Dec. 10, 1963. 17 pp.

(Contract AF 33(657)-11215, McDonnell Aircraft Corp., St. Louis, Mo.)

(A245; AD-425054)

This report describes evaluation test results of a brazed airframe section designed for optimum producibility. A uniform air pressure was applied to the test section in 2 psi increments. Deflection and set were recorded at each increment of loading. Specimen 0 sustained a uniform pressure of 30 psi without failure or visible indication of yielding. At approximately $27 \mathrm{psi}$ the root rib of specimen 1 started buckling, and failure of the specimen followed as pressure was increased to 45 psi. Failure of specimen 2 began at 37 psi as the braze between the corrugation and the spars on the compression side started to fail. Complete failure of the specimen occurred at $45 \mathrm{psi}$.

Author

N64-12648

MATERIAL - BRAZED HONEYCOMB PANELS - STRUCTURAL REPAIR - EVALUATION OF -

R. L. Jones. Nov. 4, 1963. 35 pp. Refs.

(Contract AF 33(657)-11214, General Dynamics, Ft. Worth, Tex.)

(FGT-299; AD-423075)

The present method of repairing brazed stainless-steel sandwich panels on the B-58 involves the attachment of patches by TIG spot welding techniques. This investigation has shown that the addition of certain foil brazing alloys to the fusion spot-welded joint interface of $17-7 \mathrm{PH}$ stainless steel will improve both the static lap-shear and flexure-fatigue strength. Six brazing alloys were evaluated, but only two were found to be completely satisfactory. Of these two alloys, 97Ag-3Li was the better, increasing the flexure fatigue strength by $114 \%$, and the static shear strength by $11 \%$. Three MD 1698 test panels which had 1" diameter simulated damage repairs were sonic fatigue tested. All the panels had 97Ag-3Li braze alloy added to the outer skin-patch interface. All patches passed the 3 hour test at a $160 \mathrm{db}$ sound pressure level.

Author

\section{N64-16450 \\ REFRACTORY METAL BRAZED SANDWICH DEVELOP-} MENT AND TESTING.

W. T. Kaarlela. Dec. 28, 1962. 57 pp. Refs.

(Contract AF 33(657)-11214, General Dynamics, Fort Worth, Tex., Engineering Dopt.)

(ERR-FW-188; AD-4299 22) 
A screening study established the basic process and necessary materials. The process was incorporated into an apparatus for brazing and diffusion bonding a 6 -in. $\times 6$-in. structure. The process was then expanded to produce a 12 -in. $\times$ 12-in. structure. Several good FS-82 columbium-alloy panels were brazed with $\mathrm{X}-71$ brazing alloy. Tests on specimens cut from the brazed panels demonstrated the mechanical properties at room temperature and at $2000^{\circ} \mathrm{F}$.

Author

N64-28621

2000 DEG F POWER WIRE FOR AEROSPACE ENVIRONMENT. [Quarterly Report, Apr. 5-Jul. 5, 1964]

1964. 29 pp. Ref.

(Contract AF 33(657)-11046, Melpar Inc., Falls Church, Va.)

(QR-4; AD-602144)

A brazing study was undertaken to produce reliable end seals for power-wire systems. The best results were obtained with $99.5 \%$ dense alumina end plugs, vacuum-brazed under controlled heating, cooling, and cleaning conditions. Studies of the breakdown during the $2,000^{\circ} \mathrm{F}, 1,200-\mathrm{V}$ test showed that breakdown occured over the surface of the ceramic. Small modifications of the present endseal configuration using materials already on hand show promise of overcoming this difficulty.

Author

N65-14657* \# DEVELOPMENT OF HIGH STRENGTH, BRAZED ALUMINUM, HONEYCOMB SANDWICH COMPOSITES ADAPTABLE FOR BOTH ELEVATED AND CRYOGENIC TEMPERATURE APPLICATIONS. [Third Quarterly Report, Jan.-Mar. 1964]

B. E. Kramer. 1964.85 pp.

(Contract NAS8-5445, Aeronca Mfg. Corp., Middletown, Ohio)

(NASA-CR-56305; ER-787) OTS: HC $\$ 3.00$, MF $\$ 0.75$

Following screening tests, three experimental brazing alloys were selected for reduction to foil for scaleup brazability tests. Two alloys, $85 \mathrm{Zn}-14.9 \mathrm{Al}-$ $0.1 \mathrm{Be}$ and $60 \mathrm{Zn}-39.9 \mathrm{Al}-0.1 \mathrm{Be}$ were reducible to foil. After the Al-Ge alloy proved unacceptable for foil reduction, $60 \mathrm{Zn}-40 \mathrm{Al}-0.1 \mathrm{Be}$ was substituted. Test results verify that beryllium additions to zinc-alumi num alloys promote brazability. Using the three successful brazing alloys and various combinations of six facing-sheet and two core materials, sandwich panels were fabricated and coupon samples taken. Results of tensile tests and metallographic examinations are tabulated.

E.P.V.

15

\section{N65-15675* BRAZING SHORT-CIRCUITED ROTORS OF ASYNCHRO- NOUS ELECTRIC MOTORS WITH AN MPR-100 MACHINE.}

B. M. Nekrasov, G. I. Zlobin, and Yu. A. Rusakov. Feb. 1, 1965. 5 pp.

Svarochnoye Proizvodstvo (Moscow), no. 10, Oct. 1964, pp. 39-40.

(JPRS-28564; TT-65-30246) OTS: $\$ 1.00$

A machine for the automatic brazing of large short-circuited rotors is described. The complete specifications of the machine are given, including the sizes of rotors that can be brazed in it, the rate of productivity, voltage, power, machine dimensions, machine weight, etc. The procedures that the machine follows in this manufacturing step are described briefly, and the influence on production efficiency of this machine is given.

D.E.W. 
15

\section{N65-15682 \# BRAZING OF THIN-WALLED PIPING.}

A. I. Gubin and A. N. Kitayev. Feb. 2, 1965. 57 pp.

"Svarka i Payka Tonkostennykh Truboprovodov" (Moscow), 1964, pp. 55-109.

(JPRS-28594; TT-65-30259) OTS: \$3.00

Contents:

1. Technology of brazing of piping.

2. Treatment of piping surfaces.

3. Strength of welded and brazed piping unions.

15

N65-27534\# TECHNIQUE OF MAKING A CUTTING TOOL WITH

\section{BRAZED HARD ALLOY TIPS.}

V. N. Artsimovich, E. M. Partikeyeva, I. A. Tokarev, and I. I. Yanovskiy (Air

Force Systems Command, Wright-Patterson AFB, Ohio, Foreign Technology Div.).

Apr. 7, 1965. 4 pp.

Patent No. 144559 (Appl. No. 761828/22-2, Jan. 25, 1962).

(FTD-TT-65-297/1; AD-614771)

The technique for making cutting tools with brazed, hard-alloy tips is distinguished by the fact that in order to reduce internal stresses in the braze zone and to increase durability the tool is subjected to cold hardening at a temperature of -100 to $-183^{\circ} \mathrm{C}$ after the hard alloy tip has been brazed on. Author 15

\section{N65-34426*\# SELECTED SHOP TECHNIQUES: 71 SELECTED SUGGES- TIONS FOR MACHINISTS, MECHANICS, AND TECHNI- CIANS. [Technology Handbook]}

Aug. 1965. $91 \mathrm{pp}$.

(NASA-SP-5010) GPO: \$0.60; CFSTI: MF \$0.75, CSCL 13H

This handbook contains 71 selected suggestions for machinists, mechanics, and those working in related crafts. It shows how problems of a particular type were solved, and describes how fabrication obstacles were overcome by improvis. ing, by creating new tools, or by applying an old and perhaps forgotten technique to a new field. Areas covered include shock absorbers and protective devices, special fabrication techniques, machining, metal forming (sheet metal, tubing, brakes and dies), welding and brazing, lathe attachments, precision tools, special tools and devices, and hoisting.

N65-35354*\# HIGH-PERFORMANCE THERMIONIC CONVERTER.

[Quarterly Progress Report, May 13-Aug. 13, 1965]

A. E. Campbell and D. H. Pollock. Aug. 23, 1965. 91 pp. Refs.

(Contracts NAS7-100; JPL-951225, Electro-Optical Systems, Inc., Pasadena, Calif.)

(NASA-CR-67299; EOS-6952-0-1) CFSTI: HC $\$ 3.00$, MF $\$ 0.75$, CSCL $13 \mathrm{H}$

Radiator heat-rejection studies have been concerned with investigations of coating stability, fabrication of collectors, and high temperature brazing. Rokide " $\mathrm{C}^{n}$ coatings of 0.002 " on molybdenum and copper were found to be stable at $600^{\circ} \mathrm{C}$ for periods in excess of 500 hours. Effective emissivity for these coatings is found to be 0.78 , and does not change at $600^{\circ} \mathrm{C}$ for thicknesses between $002^{\prime}$ and 006 ". There was no peeling, chipping, degradation, or evaporation of these coatings over the 500 hour test in a $10^{-7} \mathrm{~mm} \mathrm{Hg}$ ion-pumped environment. A copper radiator-molybdenum collector has been fabricated, and testing indicates that it retains the integral strength of the $\mathrm{Mb}$ collector-radiator while it is better than $\mathrm{Mb}$ on a heat-rejection-per-unit-weight basis. An Mb-collector with copper inserts has been fabricated, and calculations indicate improved effective thermal conductivity of the collector barrel. Rhenium-niobium braze joints, using vanadium as the brazing material, appear to be brittle and do not exhibit any brittle intermetallic compounds when the correct braze schedule is used.

M.W.R. 


\title{
IV - METHODS \& METHODS DEVELOPMENT
}

\author{
A63-10466 DIFFUSION BONDING TUNGSTEN.
}

M. J. Albom (The Marquardt Corp., Van Nuys, Calif.)

(AWS, 43rd Annual Meeting, Cleveland, Ohio, Apr. 9-13, 1962.)

Welding Journal, Research Supplement, vol. 41, Nov. 1962, pp. 491s-502s. 33 refs. Army-sponsored research.

A program aimed at developing optimum bonding techniques for the fabrication of rocket-nozzle assemblies is described. The objectives of the investigation are to: (1) determine and establish the brazing parameters for joining tungsten below its recrystallization temperature, (2) determine and establish diffusion techniques to raise the remelt temperature of a brazed joint to in excess of $4,000^{\circ} \mathrm{F}$, and (3) fabricate a rocket-motor nozzle using the procedures and techniques previously established.

\section{A63-20775}

\section{THE WELDING AND BRAZING OF THE REFRACTORY METALS NIOBIUM, TANTALUM, MOLYBDENUM AND TUNGSTEN - A REVIEW.}

M. H. Scott and P. M. Knowlson.

Journal of the Less-Common Metals, vol. 5, June 1963, pp. 205-244. 87 refs.

The authors review the present and future problems in the development and welding of niobium, tantalum, molybdenum, and tungsten, and their alloys. Metallurgical characteristics are discussed, as is the influence of impurities and alloying elements on mechanical properties, alloy development, and weldability. Also discussed are availability, high-temperature strength, ductility, and oxidation resistance. The general problems which will be met when welding these materials are described, together with means of assessing weld quality. Information on the welding and brazing of each material and its alloys is assessed in order to define lines of research.

\section{A64-11145 THE BRAZING OF TITANIUM TO ALUMINUM.}

F. Bollentath and G. Metzger (Rheinisch-Westfalische Technische Hochschule, Institut für Werkstoffkunde, Aachen, Germany)

(American Welding Society, Annual Meeting, 44th, Philadelphia, Pa., Apr. 22-26, 1963.)

Welding Journal, Research Supplement, vol. 42, Oct. 1963, pp. 442s-453s. 53 refs.

The problems of brazing the dissimilar metal combination of aluminum-

titanium is discussed with respect to the metal properties and previous brazing experience. An investigation of the silver-aluminum alloy system showed that, under the conditions prevailing during the experiments, a completely eutectic microstructure was obtained at $33 \mathrm{wt} \%$ aluminum. The reactions under simulated brazing conditions between titanium and the materials aluminum and its binary alloys with silver, zinc and silicon were investigated. The strength of the brazed joints of the $\mathrm{Ti}-\mathrm{Al}-\mathrm{Mg}-\mathrm{Si}$ alloy was also investigated when the brazed joint was subjected to the hardening treatment for the Al-Mg-Si alloy. A bend test of torchbrazed lap joints of the combinations $\mathrm{Ti}-\mathrm{Al}$ and $\mathrm{Ti}-\mathrm{Al}-\mathrm{Mg}-\mathrm{Si}$ alloy with the silveraluminum filler metal showed that the bend angle, before failure occurred, varied 
from 40 to greater than 90 degrees. In general, it was found that the influence of the thickness, in the range investigated, of the intermetallic-compound layer on the strength of the brazed joints was of minor significance. In was found that the form of the test specimen and the brazing process used have a much greater influence on the strength.

\section{A64-24499 JOINING OF REFRACTORY METALS.}

A. G. Metcalfe (Solar, Research Laboratories, San Diego, Calif.)

IN: The Science and Technology of Tungsten, Tantalum, Molybdenum, Niobium and Their Alloys; Proceedings of the NATO AGARD Conference on Refractory Metals, Oslo University Centre, Oslo, Norway, June 23-26, 1963.

Edited by N. E. Promisel.

AGARDograph 82.

Oxford, Pergamon Press, 1964, pp. 557-570. 12 refs.

This paper discusses the state of the art of joining refractory metals for aeronautical applications. Fusion welding adequate for aerospace applications, including electron-beam welding, tungsten electrode-inert gas (TIG), and metal electrode-inert gas (MIG), is described in terms of weld composition, atmosphere, fixturing and heat treatment, welding speed, and weld-bead contour. Resistance welding and ultrasonic and flash welding are briefly considered. High-temperature brazing of the refractory metals is described, as are reactive brazing and weld brazing. Also delineated are the processes of diffusion bonding, and pin joining. It is seen that niobium, tantalum, and moderate-strength alloys of these metals can be welded to give strengths and ductilities approaching those of wrought sheet, by arc, electron beam, and resistance welding. Alloys with restricted solubility for interstitials such as molybdenum and tungsten, plus tantalum and niobium alloys rich in the former metals, become irreversibly embrittled by recrystallization.

\section{A65-11573 EXOTHERMIC BRAZING OF SPACE AGE MATERIAIS.} Roger A. Long (Telecomputing Corp., Narmco Research and Development Div., San Diego, Calif.)

IN: Society of Aerospace Material and Process Engineers, National Symposium on Materials for Space Vehicle Use, 6th, Seattle, Wash., Nov. 18-20, 1963. Vol. 1. Seattle, Society of Aerospace Material and Process Engineers, 1963. 30 pp. Contract No. N-600(19)-59237.

Two brazing techniques which use the heat from an exothermic reaction were investigated experimentally. The first technique uses this heat to melt, within the bondline, a commercial braze alloy, the exothermic reaction material being placed "external" to the joint to be brazed. The second technique uses a similar type of reaction, but with an exothermic reaction material placed within the joint ("internal"). This produces not only the heat for brazing, but simultaneously, the braze alloy. Acceptable brazes were obtained with the Ni-Mn internal exotherm system only. It is shown that the remelt temperature of this system can be raised by a diffusion treatment, since extensive diffusion alloying occurs in the system. Even though this approach seems satisfactory, it is not considered to be a major advantage, since similar results could be obtained by furnace brazing and diffusion in one step. The feeling is expressed that the difficulty of maintaining tolerances through a cycle of this type precludes many practical applications. Therefore, further investigation of the "internal" exotherm concept was not warranted. 
E. E. Weismantel and K. C. Taber (Beryllium Corp., Reading, Pa.)

(American Welding Society, Annual Meeting, 45th, Detroit, Mich., May 4-8, 1964.) Welding Journal, vol. 43, Dec. 1964, pp. 1022-1027.

The authors discuss the characteristics of brazed beryllium joints and practical aspects of joint design and loading, as affected by notch sensitivity and mode of failure. Since the welding of beryllium is normally impractical, brazing is seen to be the preferred method of assembly where corrosion resistance, temperature resistance, or strength is requisite. Factors influencing the choice of one of the more widely used brazing alloys (zinc-, aluminum-, or silver-based) are evaluated. It is suggested that for many applications requiring beryllium brazements, the most practical approach is to use alloys with the lowest melting point. While vacuum or inert-gas furnace brazing is required with the higher-melting silver-alloy filler metals, the lower-melting braze metals can be applied in an air environment.

W.M.R.

\section{A66-15001 \# BRAZING AND DIFFUSION BONDING OF TITANIUM} ALLOYS TO SIMILAR AND DISSIMILAR MATERIALS.

Robert C. Bertossa and Tsutomu Hikido (Pyromet Co., San Carlos, Calif.) Society of Automotive Engineers, National Aeronautic and Space Engineering and Manufacturing Meeting, Los Angeles, Calif., Oct. 4-8, 1965, Paper 650752. 31 pp. Members, $\$ 0.75$; nonmembers, $\$ 1.00$

This is a review of recent developments in high vacuum and/or inert gas brazing and diffusion bonding of titanium which have permitted higher strength titanium-to-titanium joints than were previously attainable by the silver-base alloy brazing techniques, and higher strengths and corrosion resistances to rocket engine fuels in titanium-to-stainless steel brazed joints. The high-strength vacuum brazing of $6 \mathrm{Al}-14 \mathrm{~V}$ titanium alloy to Type $304 \mathrm{~L}$ stainless steel for service in the Gemini capsule is described, followed by a description of the vacuum-pressure cladding of multilayer crack-propagation-resistant 5Al-2.5Sn titanium alloy plates for atomic reactor applications. Another example discussed is the solid-state diffusion bonding of $6 \mathrm{Al}-4 \mathrm{~V}-\mathrm{Ti}$ alloy pressure spheres, where base metal strengths are attained in the bond zone.

F.R.L.

\section{A66-15002\# JOINING ALUMINUM TO STAINLESS STEEL FOR SPACE VEHICLE APPLICATIONS.}

Leo E. Gatzek (North American Aviation, Inc., Space and Information Systems Div., Downey, Calif.)

Society of Automotive Engineers, National Aeronautic and Space Engineering and Manufacturing Meeting, Los Angeles, Calif., Oct. 4-8, 1965, Paper 650754. 20 pp. 7 refs.

Members, $\$ 0.75$; nonmembers, $\$ 1.00$

Techniques are reviewed for joining aluminum to stainless steel for current and advanced spacecraft applications, including process details and illustrations to delineate the methods of joining these dissimilar metals, and to demonstrate the integrity of aluminum-stainless steel bonds. Salt-bath dip brazing of tincoated stainless steel to aluminum, employing a standard aluminum brazing alloy, has proven feasible in all respects. It is considered that fusion welding and solid-state diffusion bonding processes may, with expanded development, also become entirely feasible. Friction welding, principally intended for high productivity, appears promising. The strength, toughness, impermeability, and thermal adaptability of the metallurgical bonds have been demonstrated in simulated launch and space-flight environments. 

TUNGSTEN FOR HIGH TEMPERATURE SERVICE. [Final Report ]

C. W. Haynes. Mar. $26,1962.44$ pp. 4 refs.

(Contract NOw-61-0414-c, Solar Aircraft Co., San Diego, Calif.)

(RDR-1249-6)

This report covers the development of the platinum-boron reactive braze system for the low-temperature brazing of tungsten for high-temperature service. The effects of various boron contents in the braze alloy, of the mode of tungsten addition to the joint, of diffusion treatments, and of joint thickness were studied. Methods to improve the temperature capability of the alloy were investigated.

(Author Abstract)

N62-12233

DEVELOPMENT OF LOW TEMPERATURE BRAZING OF TUNGSTEN FOR HIGH TEMPERATURE SERVICE. [Interim Report 5, Nov. 16, 1961 through Jan. 15, 1962]

C. W. Haynes. Feb. $15,1962.14$ pp. 4 refs.

(Contract NOw-61-0414-c, Solar Aircraft Co., San Diego, Calif.) (RDR-1249-5)

The effects of variations in brazing cycle, tungsten powder addition, and diffusion treatment on the temperature required to cause joint separation at $800 \mathrm{psi}$ shear stress has been determined for lap joints brazed with $\mathrm{Pt}-2.15 \mathrm{~B}$ alloy. Further evaluation of optimum joint thickness has been made. (Author Abstract)

N62-12646

DEVELOPMENT OF LOW TEMPERATURE BRAZING OF TUNGSTEN FOR HIGH TEMPERATURE SERVICE. [Interim

Report No. 1, Mar. 28, 1961 through May 15, 1961]

C. W. Haynes and A. G. Metcalfe. May $23,1961.5$ pp.

(Contract NOw-61-0404-c, Solar Aircraft Co., San Diego, Calif.)

(Report RDR-1249-1; SO-6-0125-7)

Preliminary tests have been run in Phases I, II, and III of the program. Results indicate that the maximum usable boron content of the platinum-boron alloy is about $4.5 \%$. At heating rates up to $200^{\circ} \mathrm{F} \mathrm{min}$, powder size of the tungsten addition to the alloy up to about 74 microns has little significance in the absence of other tungsten.

(Author Abstract)

N62-14327

\section{BRAZING FOAM ALIMINUM TO SAP-I MATERIAL AND} TITANIUM ALLOY OT4.

Yu. S. Dolgov, D. L. Khadzhi, and V. L. Grishin (Moscow Aviation Technology Inst.). July $26,1962.8$ pp. 3 refs.

Svarochnoye Proizvodstvo (Moscow), No. 6, June 1962, pp. 18-20.

(JPRS-14601) Available from OTS.

An abrasive method, which does not require the use of fluxes, was successfully used for brazing foam aluminum to SAP-1 (sintered aluminum powder) and for brazing titanium alloy OT4 using preliminary tinning of the foam aluminum with zinc-base brazes. The working temperature should not exceed $500^{\circ}-510^{\circ} \mathrm{C}$; higher temperatures cause swelling of SAP-1 and deformation of the cells in foam aluminum. Joints brazed by this method exhibited satisfactory shear strength at $20^{\circ}$ and at $300^{\circ} \mathrm{C}$. Tests of brazed joints in sea water and in a humid chamber for a period of 15 days indicated satisfactory corrosion resistance of the joints. M.P.G. 
H. E. Pattee and R. M. Evans (Defense Metals Information Center, Battelle Memorial Inst., Columbus, Ohio). June 11, 1962. 26 pp. 38 refs.

(DMIC-Memo-153)

Many of the important developments in the joining of columbium, molybdenum, tantalum, tungsten, and graphite are summarized. Much of the subject matter is devoted to the brazing processes; however, diffusion and solid-state bonding are also covered. The particular properties which recommend the refractory metals and graphite to aerospace applications are discussed. Adverse properties, which limit the use of these materials or which must be overcome by using special precautions, also are mentioned. Typical filler metals used to join the refractory materials for low- as well as high-temperature service are covered. The hightemperature aspects of joining are emphasized.

(Author Abstract)

N63-11011 QUARTZ LAMP RADIANT HEAT BRAZING OF LARGE REFRACTORY METAL HONEYCOMB SANDWICH PANELS. [Interim Engineering Progress Report, July 10-0ct. 10, 1962]

D. B. Hugill and B. Gaiennie. $1962.65 \mathrm{pp} .28$ refs.

(Contract AF 33(657)-9810, Northrop Corp., Norair Div., Hawthorne, Calif.)

(IR-7-937a(1))

This project is planned to develop manufacturing methods and design criteria for refractory-metal brazed-sandwich structures of sufficient size to be practical for aerospace vehicles. The quartz lamp radiant heating system will be used. Investigation has demonstrated that diffusion-bonded honeycomb core can be produced and that successful brazing can be accomplished under time, temperature, and inert gas atmosphere conditions representative of the quartz lamp radiant brazing system.

Author

\section{N63-12583}

JOINING OF NICKEL-BASE ALLOYS.

R. M. Evans. Dec. 20, 1962. 77 pp. 60 refs.

(Contract AF 33(616)-7747, Defense Metals Information Center, Battelle Memorial Inst., Columbus, Ohio)

(DMIC-181)

The key to the success of many devices that are to be used in corrosive or high-temperature environments is often an ability to weld the nickel-base alloys properly. Alloys such as Monel, Inconel, etc., that do not depend upon relatively complex metallurgical reactions to obtain their desirable properties are not difficult to weld if proper procedures are used. Alloys which are relatively new (René 41, Hastelloy R-235, Inconel X, etc.) and do depend on complex metallurgical reactions to develop their useful properties present many joining problems. This report covers in a general way the criteria for the successful fabrication of several alloys which fall in each category. Fusion welding, resistance welding, and brazing are covered. The welding of dissimilar nickel-base-alloy combinations and repair welding are also discussed.

Author

N63-13980

JOINING OF REFRACTORY METALS-TUNGSTEN. [Final Report ]

J. H. Brophy, H. Heideklang, P. Kovach, and J. Wulff. Mar. 30, 1962. 59 pp.

34 refs.

(Contract DA-19-020-ORD-5236, Massachusetts Inst. of Tech., Cambridge)

(WAL-TR-460.54/1-2)

Concepts of activated tungsten diffusion have been applied to the joining of tungsten strip at temperatures ranging from $900^{\circ}$ to $1100^{\circ} \mathrm{C}$. Solid-state diffusion 
has been enhanced by electroplating a thin layer of either nickel or palladium on one of the mating surfaces. Assemblies were made by heat treating in a hightemperature vise or by spot welding followed by a diffusion treatment. Joints were in sandwich, single-lap, or double-lap geometries. Fractography, metallographic examination, bend tests, and tensile-shear-loading tests indicated that bonding could be accomplished at temperatures as low as $1000^{\circ} \mathrm{C}$. The structure was typically partially recrystallized but free of thermal cracks. The joints were brittle at room temperature, but specimens heated to $2200^{\circ} \mathrm{C}$ remained capable of bearing a load. A brief theoretical discussion and an interpretation in the light of other joining techniques have been offered.

Author

\section{N63-22966 BRAZING OF TITANIUM WITH RAPID HEATING.}

I. I. Il'yevskiy and N. S. Kochukov. Oct. 14, 1963.

Svarochnoye Proizvodstvo (Moscow), No. 5, 1963, pp. 21-24.

(JPRS-21437: OTS-63-31935) OTS: $\$ 0.50$

The problem of soldering titanium alloys during rapid heating in salt baths is discussed. The results of tests of the mechanical properties of the soldered joints depending on the influence of the thermal cycle of soldering are presented.

Author

N64-10034

CLADDING BETWEEN ALPAX AND SINTERED AL-AL $\mathbf{O}_{3}$, APPLICATION TO BRAZING OF PIECES OF SINTERED $\mathrm{Al}-\mathrm{Al}_{2} \mathrm{O}_{3}$. [EXAMEN DE PLACAGES ALPAX/FRITTE Al$\mathrm{Al}_{2} \mathrm{O}_{3}$ APPLICATION AU BRASAGE DE PIECES EN FRITTE $\mathrm{AL}^{-\mathrm{Al}_{2} \mathrm{O}_{3}}$

J. Herenquel and C. Leymonie (TREFIMETAUX). July 1963. 26 pp. Ref. In French; English summary. Presented at the Journées Mét d'Automne, Paris, Oct. 15-19, 1962.

(Contract EURATOM/T.L.H.-004-60-9 ORG F)

(EUR 274.f) Available from Belgian American Bank and Trust Co., N.Y., account No. $121.86 ; 40$ Belg. Fr.

Co-rolling was used to carry out studies on alpax-sintered $\mathrm{Al}-\mathrm{Al}_{2} \mathrm{O}_{3}$ joints. Acceptable bonds were obtained as a result of co-rolling at $350^{\circ}$ and $450^{\circ} \mathrm{C}$. However, after annealing at high temperatures $\left(450^{\circ}, 500^{\circ}\right.$ and $\left.560^{\circ} \mathrm{C}\right)$ designed to simulate the temperature conditions to which the cladding is likely to be subjected in practice, a noticeable stripping of the silicon particles in the alpax was observed in the diffusion zone. This stripping is a nuisance from the technical point of view (source of brittleness, risk of loss of leaktightness). The same experiments were carried out again, the normal alpax being replaced by a grade to which $0.02 \%$ of sodium has been added. Under these conditions the diffusion was no longer disturbed by the presence of coarse particles of silicon, and the diffusion zone is free of incipient internal fractures. Tests have been carried out on sheets of sintered $\mathrm{Al}-\mathrm{Al}_{2} \mathrm{O}_{3}$ and on units consisting of a bar and a tube. The bond obtained is, in all cases, of good quality, unimpaired by diffusion. The brazings obtained have a high mechanical resistance, which under certain conditions is superior to that of the sintered materials themselves. Furthermore, they are entirely unaffected by helium.

Author

N64-10334*

EFFECT OF TWO BRAZE COATINGS, PROCESSING VARIABLES, AND HEAT TREATMENTS ON $1200^{\circ} \mathrm{F}$ STRESSRUPTUAE STRENGTH OF I,-605, A-286, AND INCONEL 700 SHEET.

John H. Sinclair and Charles A. Gyorgak (Washington, NASA). Nov. 1963. 55 pp. Refs.

(NASA TN D-1880) OTS: $\$ 1.50$ 
The nickel-base braze alloys and brazing processes investigated affect the stress-rupture life of L-605, A-286, and Inconel 700 sheet materials. The thermal treatment required to braze improves the life of L-605 but is detrimental to A-286 and Inconel 700. Boron-bearing braze (Ni-Cr-Si-B) improves the stress-rupture life of L-605 and Inconel 700, but decreases the stress-rupture life of A-286. L-605 coated with boron-free braze ( $\mathrm{Ni}-\mathrm{Cr}-\mathrm{Si})$ has better stress-rupture properties than L-605 in the as-received condition, because the temperature cycle required for brazing improves the stress-rupture properties of $\mathrm{L}-605$. Ni-Cr-Si improves the life of Inconel 700 and is less detrimental to A-286 than Ni-Cr-Si-B.

Author

N64-10750 BRAZING AND WELDING SINTERED ALUMINUM POWDEK. Yu. V. Dmitriyev et al. Mar. 18, 1963. 26 pp. Refs.

Svarochnoye Proizvodstvo (Moscow), No. 11, 1961, pp. 7-13.

(JPRS-18187; OTS-63-21349) OTS: \$0.75

Investigations were conducted using sheet material of SAP (sintered aluminum powder). The possibility of obtaining welded bonds of SAP sheets was demonstrated, and the technique for spot welding was developed. The technology for the cladding of SAP with various aluminum alloys is described. A method for spot and seam welding of SAP sheets was developed, the welded bonds of the clad SAP have high strength at room and at elevated temperatures. Results are also presented from investigations on the brazing of SAP materials, using zinc and aluminum solder, by the abrasion, gas flame, and elcctrocontact methods. R.T.K.

\section{N64-11271}

\section{CERTAIN PROBLEMS INVOLVED IN THE BRAZING OF TITANIUM ALLOYS.}

A. Ya. Shinyayev and V. V. Bondarev. Dec. 2, 1963. 12 pp. Refs. Svarochnoye Proilzvodstvo (Moscow), No. 10, Oct. 1963, pp. 15-17. (JPRS-22096; OTS-63-41266) OTS: $\$ 0.50$

The formation of the diffusion zone between titanium (or its alloys) and various galvanic coatings during brazing with copper-silver solders was investigated. Results indicate that the maximal strength of a brazed joint of titanium alloys can be obtained under temperature conditions that correspond to the creation of a diffusion zone, in the form of a solid solution, with a finely dispersed segregation of the foci of the second phase with a value not in excess of $3000 \AA$. The diffusionzone structure is fixed by the rate of the mutual diffusion between the $\mathrm{Ti}$ and the electroplating. This rate is the determining factor in the selection of the type of electroplating for a given range of brazing temperatures.

R.T.K.

\section{N64-16840 THE INVESTIGATION OF EXOTHERMIC BRAZING OF}

REFRACTORY ALLOYS. [Final Technical Report, Nov. 1, 1962-0ct. 31, 1963]

Roger A. Long and Ray Williams. Dec. 1963. $37 \mathrm{pp.}$ (Contract N600(19)-59237, Telecomputing Corp., San Diego, Calif., Narmco Research and Develop.)

(AD-432137) OTS: $\$ 3.60$

The following concepts for brazing refractory metals utilizing exothermic reactions were investigated: (1) an external exothermic heat source used to produce a joint with a standard braze alloy; (2) exothermic reactions (internal exotherms) whose reaction products include a metal phase that serves as the braze alloy; (3) an external exothermic heat source used to produce a joint by means of a fluxing ceramic phase. Studies carried out under concept (2) resulted in exotherms that yielded a satisfactory nickel-manganese braze alloy. Exothermic reactions (external) that act as heat sources (concept 1 ) were successful in 
producing high-strength brazed joints with all the refractory metals when using commercially available braze alloys with flow temperatures up to $3,100^{\circ} \mathrm{F}$. The feasibility of using a boron "donor" compound to produce an "in-situ" braze alloy with the base metal (concept 3) was proven.

Author

N64-18977 GAS-FLAME BRAZING OF METALS.

G. A. Asinovskaya. Apr. 24, 1964. 119 pp. Refs.

"Gazoplamennaya payka metallov" (Moscow), State Sci. and Tech. Publ. House for Machine-Building Lit., 1963, pp. 1-128.

(JPRS-24345; OTS-64-31152) OTS: $\$ 2.50$

Problems relative to gas-flame brazing with low- and high-melting point braze metals are elucidated, data necessary for the use of new equipment and apparatus are presented, the technological peculiarities of braze metals of various metals and alloys are explained, and data on safety techniques are offered.

Author

\section{N64-18979 BRAZING SAP-2 SINTERED ALUMINUM POWDER.}

V. L. Grishin. Apr. 27, 1964. 9 pp. Refs.

Tsvetn. Metal. (Moscow), No. 1, Jan. 1964, pp. 58-62.

(JPRS-24355; OTS-64-31160) OTS: \$0.50

Brazing sintered aluminum powder (SAP) and the heat resistance of these joints were investigated. The following methods are discussed: (1) abrasive brazing; (2) resistance brazing; (3) dip brazing; (4) furnace brazing. Mechanical and corrosion tosts of the joints are also discussed.

R.T.K.

N64-27230*

\section{BRAZING AND WELDING OF BERYLLIIM. [HARTLOTEN UND SCHWEISSEN VON BERYLIIIIM]}

H. Weik. Jul. 1964 . 29 pp. Refs.

Metallwiss. und Tech., Vol. 18, No. 3, 1964, pp. 235-243.

(NASA TT-F-9021)

Recent developmental work in beryllium metallurgy is described. The state of technology of brazing and welding of beryllium is examined. Suitable joints have been obtained as follows: in the case of rods, by butt brazing in a vacuum and by resistance butt brazing at current intensities above $80,000 \mathrm{~A} / \mathrm{cm}^{2}$; in the case of sheets, by spot brazing; and welding, and by arc welding. Ultrasonic welding processes for the welding of beryllium sheets to each other and to other metals are also described.

R.T.K.

\section{N64-31095 ELECTRON BEAM BRAZING OF BERYLIIJM.}

E. F. Deesing (Naval Air Engineering Center, Philadelphia, Pa., Aoronautical Materials Lab.) Jul. 27, 1964. 4 pp.

(NAEC-AML-1997; AD-603192) OTS: \$1.00

Eleven filler metals were used in bead tests under vacuum using a defocused electron beam-high purity $\mathrm{Ag}, \mathrm{Ag}-\mathrm{Cu}$ eutectic alloy, $\mathrm{Ag}$ braze alloy, $\mathrm{Ag}$ sterling alloy, Ag-0.3\% Li alloy, Ag-1.0\% Be alloy, Ag-5\% Al alloy, high-purity $\mathrm{Al}, \mathrm{Al}-12 \%$ $\mathrm{Si}$ alloy, $\mathrm{Zn}-\mathrm{Al}-\mathrm{Cu}$ alloy, and commercially pure $\mathrm{Zn}$. Brazing of beryllium was attempted with those filler metals that appeared to molt and to wet titanium alloy. However, these filler metals exhibited very poor wettability on chemically cleaned beryllium surfaces. The $\mathrm{BeO}$ content of the sintered beryllium apparently inhibited the wettability and flow of the filler metals. The highly reactive beryllium surface also contributed to the poor wettability by combining with extraneous elements present in the filler metal. It was also concluded that electron-beam heating was not practical for the brazing procoss because of the intense localized heating offect produced oven at low-energy outputs. Other means of heating in vacuum would be more practical.

R.L.K. 

ATMOSPHERES.

R. Ye. Esenberlin. Nov. 6, 1964. 107 pp. Refs.

Payka Metallov v Pechakh s Gazovoy Sredoy (Leningrad), 1958.

(JPRS-27273; TT-64-51528) OTS: $\$ 4.00$

This book presents the physicochemical bases and technological characteristics of brazing metals and alloys in controlled atmospheres, and describes the equipment needed for this purpose. The most widespread braze metals and gases used for nonoxidative brazing processes are cited.

Author

N65-10898 \# JOINING OF REFRACTORY METAL FOLLS. [Technical Documentary Report, Jul. 1962-Jul. 1963]

J. W. Welty, P. J. Valdez, C. E. Smeltzer, Jr., and C. P. Davis (Wright-Patterson AFB, Ohio, ASD). Jul. 1963. 205 pp. Refs.

(Contract AF 33(657)-9442, Solar, San Diego, Calif.)

(ASD-TDR-63-799, Pt. I; AD-424651)

Standard methods of welding and brazing refractory metal foils (D36, B66, and TZM) are presented. Electron beam, tungsten-inert-gas, resistance, and ultrasonic welding techniques are evaluated. Nine selected candidate brazing alloys for these materials were screened by means of $T$-joint brazements, room-temperature and high-temperature mechanical property tests, and metallographic structure examination. The most promising joining methods for these materials were extended to the fabrication of small honeycomb panels $(0.002$-in. core, 0.010 -in. face sheets) that were block-shear tested at temperatures between $2000^{\circ}$ and $2800^{\circ} \mathrm{F}$.

Author

\section{N65-11318 \#}

\section{DIFFUSION BRAZING OF NONFERROUS METALS AND ITS POSSIBILITIES.}

N. F. Lashko and S. V. Lashko. Nov. $23,1964.11$ pp. Refs.

Tsvetn. Metal. (Moscow), No. 8, pp. 86-90.

(JPRS-27502; TT-64-51751) OTS: $\$ 1.00$

The general process of diffusion brazing, a variety of capillary brazing in which the brazed seam hardens from the liquid state without cooling, while keeping the braze metal at a higher temperature than that of the solidus line, is described. The details of several methods of diffusion brazing, braze metals for various base metals, the hardening mechanism of the brazed seam, and metallurgical examinations of brazed seams are described.

D.E.W.

\section{N65-11678 \# STUDIES IN BRAZING OF TITANIUM AND ELECTRO- SLAG WELDING.}

Dec. 3, 1964. $22 \mathrm{pp.}$

Svarochnoye Proizvodstvo (Moscow), No. 9, Sep. 1964.

(JPRS-27673; TT-64-51860) OTS: $\$ 1.00$

The process of brazing titanium and its alloys, using an electroplated copper coating, was studied. Brazing was done at various temperatures, and at various constant pressures, and at various holding times.

Author

N65-12196\#

TANTALUM AND MOLYBDENUM BRAZING TECHNIQUES.

[Technical Documentary Report, June 1, 1963-June 30, 1964]

A. H. Freedman, L. H. Stone, and E. B. Mikus. Sept. 1964. 151 pp. Refs. (Contract AF 33(657)-11227, Northrop Corp., Norair Div., Hawthorne, Calif.)

(ML-TDR-64-270; AD-606576) 
Development is discussed of molybdenum and tantalum braze systems that braze at relatively low temperatures but develop high remelt and service temperatures. The most promising method of developing high remelt temperatures involved the diffusion-sink brazing approach. A $\mathrm{Ti}-25 \mathrm{Cr}-13 \mathrm{Ni}$ diffusion-sink braze alloy that melted at $2200^{\circ} \mathrm{F}$ produced the highest remelt temperatures on TZM $\left(>3100^{\circ} \mathrm{F}\right)$. Pure titanium, Ti-30V and $33 \mathrm{Zr}-34 \mathrm{Ti}-33 \mathrm{~V}$ diffusion-sink braze alloys produced the highest remelt temperatures on Ta-10W $\left(>3800^{\circ} \mathrm{F}\right)$. Pure titanium, Ti-30V and $33 \mathrm{Zr}-34 \mathrm{Ti}-33 \mathrm{~V}$ diffusion-sink braze alloys (along with the alloy $\mathrm{Cb}-1.3 \mathrm{~B}$ ) were evaluated on the Ta-8W-2Hf and Ta-30Cb-7.5 V alloys. The teeand lap-joint strengths were equivalent to those achieved on Ta-10W. Development of high remelt temperatures by using the diffusion-sink brazing approach was demonstrated on TZM and tantalum alloys.

P.V.E.

15

N65-15680\# BRAZING STAINLESS STEELS AND HEAT-RESISTING ALLOYS.

A. I. Gubin. Feb. 1, 1965. 131 pp. Refs.

"Payka Nerzhaveyushchikh Staley i Zharoprochnykh Splavov" (Moscow), 1964, pp. 1-128.

(JPRS-28572; TT-65-30250) OTS: \$4.00

- The subjects covered are: (1) Design of Stainless Steel and Heat-ResistingAlloy Braze Joints. (2) Brazing Proparation. (3) Brazes for Stainless Steels and Heat-Resisting Alloys. (4) Brazing Fluxes and Gas Media. (5) Brazing Methods. (6) Quality Control of Braze Joints. (7) Safety Engineering in Melting Brazing Alloys and in Brazing.

R.L.K.

15

N65-20201 \# STUDIES IN THE BRAZING AND SOLDERING OF METAL ALLOYS.

Mar. 2, 1965. 27 pp. Refs.

3 Articles from Russian Publ.

(JPRS-28946; TT-65-30414) CFSTI: $\$ 2.00$

Contents:

1. SOLDERING OF ALUMINUM TO STEEL. V. R. Ryabov and Ye. O. Paton, p. 1-8, refs. (See N65-20202 10-15).

2. (a) INTERACTION OF SOLDER WITH THE MATERIAL BEING

SOLDERED. (b) DISSOLUTION OF BASE METAL DURING SOLDERING. N. F. Lashko and S. V. Lashko, p. 9-19, refs. (See N65-20203 10-15).

3. INVESTIGATION OF DIFFUSION PROCESS IN THE BRAZING OF TITANIUM ALLOYS. A. Ya. Shinyayev and V. V. Bondarev, p. 20-24, refs. (See N65-20204 10-15).

15

\section{N65-20202 SOLDERING OF ALUMINUM TO STEEL.}

V. R. Ryabov and Ye. O. Paton

IN: Studies in the Brazing and Soldering of Metal Alloys, Mar. 2, 1965, pp. 1-8.

Refs.

Mashinostr. (Kiev), No. 6, 1962, pp. 53-56.

(See N65-20201 10-15) CFSTI: $\$ 2.00$

Methods of soldering aluminum and its alloys to steel are surveyed. Difficul-

ties in soldering aluminum to steel caused by differences in their physicochemical characteristics are discussed. A number of soldering methods are outlined, most of which involve prior coating of the aluminum or steel-or both-surfaces with flux metals such as tin, zinc, or copper. The metallic composition of the solder is given for each procedure. An ultrasonic soldering method is described. J.M.D. 
17

N65-23382

WELDING TITANIUM ALLOYS TO NICKEL-BASE ALLOYS.

I. G. Gorin

IN: Soviet Titanium Alloys, Apr. 19, 1965, pp. 42-53.

Svarochnoye Proizvodstvo (Moscow), No. 12, Dec. 1964, pp. 25-28.

(See N65-23375 13-17) CFSTI: $\$ 3.00$

Results of experiments on the welding and brazing of joints of the titanium alloys OT4-1 with the nickel-base alloy E1894 are presented. Satisfactory results in the welding of titanium alloys with nickel alloys can be obtained through the use of intermediate inserts of niobium and beryllium bronze in argonare welding and with the use of niobium or molybdenum in contact welding. It should be as sumed that after development of the production of the bimetal (titanium-stainless steel, with a shearing strength of 4 to $5 \mathrm{~kg} / \mathrm{mm}^{2}$ ), the welding of titanium alloys to chromium-nickel alloys and to steels by the use of inserts of bimetal will be the most widespread and cheapest method.

Author

\section{N65-29743*\# THERMOELECTRIC BONDING STUDY. [Progress Report No. 8, Mar. 1-31, 1965]}

[1965] 2 pp.

(Contract NAS5-3973, Hittmann Associates, Inc., Baltimore, Md.)

(NASA-CR-64023) CFSTI: HC \$1.00; MF \$0.50. CSCL 09A

Efforts during the report period have been concentrated on the thermoelectric element test fixture. Preliminary design and layout drawings of the test system have been completed. The system will consist of four individually controlled inert-atmosphere chambers, each capable of testing six thermoelectric elements at hot temperatures up to $1000^{\circ} \mathrm{F}$ and cold junction near room temperature. Provisions have been made for measuring hot and cold junction temperatures, voltage, power output, and element resistance. Extension of the previously developed braze process to $\mathrm{Pb}-\mathrm{Sn}$-Te material and to the brazing of samples of diameter other than one-half inch has been undertaken.

N.E.A.

N65-29747*\# THERMOELECTRIC BONDING STUDY. [Quarterly Progress

June $30,1965.10 \mathrm{pp.} \mathrm{Ref.}$ Report, Mar. 1-May 31, 1965]

(Contract NAS5-3973, Hittmann Associates, Inc., Baltimore, Md.)

(NASA-CR-64017; HIT-170) CFSTI: HC \$1.00; MF \$0.50. CSCL 13H

In order to optimize the bonding of lead telluride thermoelectric elements to iron with tin telluride or titanium-modified tin telluride braze, an apparatus is being constructed to test individual PbTe thermoelectric elements. The test system is designed to measure the hot-junction and cold-junction temperatures, output voltage, power output, and element resistance of each element under operating conditions for periods from 100 to 5000 hours. A hot-pressing fabrication process for $\mathrm{Pb}-\mathrm{Sn}-\mathrm{Te}$ and $\mathrm{n}-\mathrm{PbTe}$ elements is described. Room temperature electrical resistivity and Seebeck coefficient at $100^{\circ}$ to $200^{\circ} \mathrm{C}$ were measured on all elements. The $\mathrm{n}-\mathrm{PbTe}$ samples were generally within $10 \%$ of the published values. A tin soldering process for attaching cold shoes to thermoelectric elements has been investigated. A description of the brazing process and a method for preparation of the materials used in joining iron hot shoes to $\mathrm{PbTe}$ and $\mathrm{Pb}-\mathrm{Sn}-\mathrm{Te}$ is given. M.R.W.

N65-29779* \# THERMOELECTRIC BONDING STUDY. [Monthly Progress

[1965] 2 pp. Report No. 9, Apr. 1-30, 1965]

(Contract NAS5-3973, Hittmann Associates, Inc., Baltimore, Md.)

(NASA-CR-64034) CFSTI: HC \$1.00; MF \$0.50. CSCL 13H 
Activities in a thermoelectric bonding study are reported. A thermoelectric element test fixture design was completed. Approximately $100 \mathrm{p}$-type $\mathrm{Pb}$-Sn-Te elements were fabricated for property evaluation and for use in braze process optimization. Satisfactory correlation with property values was obtained. Results indicate that the bonding process developed for $\mathrm{p}-\mathrm{PbTe}$ is not completely satisfactory for $\mathrm{p}-\mathrm{Pb}-\mathrm{Sn}-\mathrm{Te}$. The braze cycle is being modified to obtain bonds comparable to those made with the $\mathrm{p}-\mathrm{Pb}$ Te material.

R.N.A.

\section{N65-32767 \#}

\section{FEASIBILITY OF BRAZED JOINTS BETWEEN Cb-Zr ALLOY AND ALUMINA CERAMICS.}

R. S. Kirby and J. D. La Mutte. Aug. 25, 1965. 26 pp. (Contract W-7405-ENG-36, Los Alamos Scientific Lab., N. Mex.)

(LA-3302-MS) CFSTI: $\$ 2.00$

Two brazing systems were developed which resulted in ceramic-metal seals whose helium leak rate was less than $1 \times 10^{-9} \mathrm{cc} / \mathrm{sec}$. Nickel plated Mo-Mn metallized $\mathrm{Al}_{2} \mathrm{O}_{3}$ ceramics were brazed to $\mathrm{Cb}$ - $\mathrm{Zr}$ metal components using a $55 \mathrm{Cu}$ $45 \mathrm{Ni}$ filler alloy. Unmetallized $\mathrm{Al}_{2} \mathrm{O}_{3}-0.5 \mathrm{Y}_{2} \mathrm{O}_{3}$ ceramics were brazed to $\mathrm{Cb}-1 \mathrm{Zr}$ metal components using a $48 \mathrm{Ti}-48 \mathrm{Zr}-4 \mathrm{Be}$ alloy. Both types of joints remained leak-tight during limited cycling tests. Neither system was considered suitable for use above $1000^{\circ} \mathrm{C}$ as developed.

Author

N65-35114*\# TIIERMOELECTRIC BONDING STUDY. [Summary Report] Abraham L. Eiss. Mar. 1965. 63 pp. Refs. (Contract NAS5-3973, Hittmann Associates, Inc., Baltimore, Md.)

(NASA-CR-67282; HIT-163) CFSTI: HC \$3.00; MF \$0.75. CSCL 13H

A study was conducted of the bonding process and the bond failure mechanisms in lead telluride thermoelectric elements, and to develop a satisfactory braze and shoe system for the material. Through a literature survey and an analytical evaluation of available metallurgical data, potential braze and shoe materials for use with lead telluride were selected. Screening was done by conducting wettability tests and accelerated poison-effects tests. Tin telluride was found to be the braze having the smallest deleterious effect on the thermoelectric properties of lead telluride. A bonding process was developed and elements prepared and evaluated metallographically by bond resistance measurements and by torque tests. A concurrent stress analysis identified the main thermal stress patterns present in bonded thermoelements and showed how they could be applied to the lead telluride bonding problem. Many shoe and braze materials will bond with lead telluride but will not survive for extended periods of time under thermoelectricgenerator operating conditions. Poisoning by material diffusion into the thermoelectric material and thermal stresses at the bond interface are the two main causes of failure.

R.N.A.

N65-35765 \#

TANTALUM AND MOLYBDENIM BRAZING TECHNIQUES. [Quarterly Progress Report No. 6, Jan.-Mar. 1965]

A. H. Freedman, L. H. Stone, and E. B. Mikus. Apr. 1965. 24 pp. Refs. (Contract AF 33(657)-11227, Northrop Corp., Norair Div., Hawthorne, Calif.) (NOR-65-68; AD-615452)

A determination was made of the reusability of titanium-base diffusion sink systems at $3000^{\circ} \mathrm{F}$ and the $\mathrm{Hf}-40 \mathrm{Ta}$ convontional braze alloy at $3500^{\circ} \mathrm{F}$ on $\mathrm{Ta}-10 \mathrm{~W}$ honeycomb structures. Low-volatile and volatile-free diffusion sink braze systems for $\mathrm{Ta}-10 \mathrm{~W}$ honeycomb were screened for applicability to $3500^{\circ} \mathrm{F}$ reusable service. Processing techniques were investigated for improving remelt and service temperature potential of the Ti-25Cr-3Be diffusion sink system for TZM. Precoating of a Ti-50Tadiffusion-sink braze joint with vacuum-deposited tantalum was investigated as a solution to the coating-braze alloy interaction problem. R.N.A. 


\section{V-TESTING \& EVALUATION}

\section{A66-10973 \\ IN SITU TESTING OF BRAZED HYDRAULIC PIPE JOIN'TS IN AIRCRAFT.}

J. Boraston (British Aircraft Corp. (Operating), Ltd., Filton Div., Bristol, England) and B. Harris-Maddox (Ultrasonoscope Co., Ltd., London, Englumi) Ultrasonics, Vol. 3, Oct.-Dec. 1965, pp. 175-181.

A contact scanning ultrasonic method has been developed for in-place testing of brazed joints in aircraft hydraulic systems. A description of the problems encountered using conventional methods of testing is followed by a consideration of the ultrasonic facility, its use, and the results obtained. Finally the advantages and disadvantages of the process are mentioned, and a possible future development is pointed out.

B.B.

\section{N64-16635 BRAZED TITANIUM - ATMOSPHERIC EXPOSURE- EVALUATION.}

E. W. Turns. Jan. 15, 1964. 5 pp. Ref.

(Contract AF 33(657)-11214, General Dynamics, Fort Worth, Tex.)

(FTDM-2988; AD-430513)

Two brazed RS 140 titanium panels were placed on the laboratory roof at a $45^{\circ}$ inclination facing south. Panel $\mathrm{S} / \mathrm{N} 703467$ was removed after 1 year of weathering, and panel S/N 723927 was removed at the end of a 2 -year period. Upon removal, the panels were cut up and physically tested (load tests), as described in FZR-125. Results are: (1) The data reduction on the 1-year test panel shows that either the panel braze was of inferior quality or that the strength had been lowered by weathering. Failure occurred primarily in the braze alloy rather than at the braze-to-titanium interface. (2) The data reduction on the 2-year test panel shows that the panei obvivusly had adequate strength. Examination of test failure areas revealed predominant core-to-braze-alloy-interface failures, with no evidence of any type of corrosion. Thus, it can be concluded that 2 years of weathering on the brazed titanium panel did not appreciably affect its physical strength.

N64-17131

\section{EVALUATION OF BRAZING ALLOYS FOR THE FABRI- CATION OF INCONEL 718 HONEYCOMB SANDWICH PANELS.}

Frank J. Coffey. Mar. 10, 1964. 33 pp.

(Contract AF 33(657)-11215, McDonnell Aircraft Corp., St. Louis, Mo.)

(A469; .AD-431616)

A nickel-base structural alloy, Inconel 718 , has been considered for use in the fabrication of honeycomb structures capable of sustained operation at elevated temperatures. Four gold-containing braze alloys were selected for compatibility testing with Inconel 718 base metal. From the results of these tests Premabraze 128 and Premabraze 130 braze alloys appeared to be suitable for honeycomb-structure brazing with Inconel 718 as base metal. No evidence was found that either of these braze alloys are susceptible to crevice corrosion. The Nicoro and Incuro 20 braze alloys were eliminated from testing because of inferior wettability and flow characteristics.

Author 


\section{N64-22575 EVALUATION OF BRAZED HONEYCOMB SANDWICH WITH 6061 FACE SHEETS AND 3003 CORE.}

James Krieg. June 10, 1964. 9 pp.

(Contract AF 33(657)-11215, McDonnell Aircraft Corp., Systems Lab., St. Louis, Missouri)

(A729; AD-441156)

Specimens were sectioned from the honeycomb panel and prepared for metallurgical examination. Photomacrographs and photomicrographs were taken of the brazed joints. Each of the core-to-face skin joints examined showed a brazed metallurgical joint, as well as a strong tendency of the braze alloy to form fillets. Although most of the joints exhibited a sound microstructure, approximately $25 \%$ of the joints examined contained large pores.

R.T.K.

15

N65-17131 \# THE NONDESTRUCTIVE TESTING OF BRAZED JOINTS.

Akira Kanno. Nov. 1964. 30 pp. Refs.

(Contract W-31-109-ENG-38, Argonne National Lab, Metallurgy Div.)

(ANL-6924) OTS: $\$ 2.00$

Three nondestructive testing methods-X-ray radiography, neutron radiography, and ultrasonic testing-were compared for detecting faults in brazed joints having a width of $0.0254 \mathrm{~mm}$. Base metals used was mainly ASTM $304 \mathrm{SS}$. Brazing alloys containing thermal-neutron-sensitive elements were chosen. As standard brazing faults, brazing-alloy foils with thicknesses ranging from 0.0127 to $0.0762 \mathrm{~mm}$, and containing various artificially induced holes were sandwiched between base metals with thicknesses in the range from 1.59 to $6.35 \mathrm{~mm}$. R.L.K.

22

\section{N65-23646 \# IRRADIATION DAMAGE TO CERAMICS, METALLIC- CERAMIC BONDS, AND BRAZING ALLOYS.}

Alton J. Patrick. Apr. 26, 1965. 49 pp. Refs.

(Contract W-7405-ENG-36, Los Alamos Scientific Lab., N. Mex.)

(LA-3285-MS) CFSTI: $\$ 3.00$

Irradiation damage to ceramics, metallic-ceramic bonds, and brazing alloys is described for a temperature range of $700^{\circ}$ to $970^{\circ} \mathrm{K}$. Data are presented for an accumulated thermal-neutron flux from $1.36 \times 10^{21}$ to $2.77 \times 10^{21}$ and for an accumulated fast-neutron flux $(>1 \mathrm{MeV})$ from $1.5 \times 10^{20}$ to $3.17 \times 10^{21}$. In this range the samples tested of $\mathrm{BeO}-\mathrm{MgO}$, magnesia spinel, and $\mathrm{Y}_{2} \mathrm{O}_{3}$ were found unsatisfactory. The 97.5\% $\mathrm{Al}_{2} \mathrm{O}_{3}(\mathrm{Al}-300), 98 \% \mathrm{Al}_{2} \mathrm{O}_{3}+2 \% \mathrm{Y}_{2} \mathrm{O}_{3}(\mathrm{Al}-13)$, and $99.5 \% \mathrm{Al}_{2} \mathrm{O}_{3}+0.5 \%$ $\mathrm{Y}_{2} \mathrm{O}_{3}(\mathrm{Al}-14)$ were found the most resistive to irradiation damage. The electrical resistivity of the ceramics tested was lower after irradiation.

Author

\section{N66-13905\# X-RAY EXAMINATION OF SQUARE WATER-COOLED COPPER MAGNET-CONDUCTOR BRAZE JOINTS.}

Richard A. Nickerson. Sept. 1, 1965. 11 pp.

Presented at the 1st Intern. Symp. on Magnet Technol., Stanford, Calif.

(Contract W-7405-ENG-48, Lawrence Radiation Lab., Univ. of Calif., Berkeley)

(UCRL-16383; Conf-650922-11) CFSTI: HC $\$ 1.00$; MF $\$ 0.50$

Brazed-joint design and fabrication technology was improved by $\mathrm{X}$-ray quality control in early stages of magnet coil production. The $X$-ray techniques discussed, though simple, require consideration of geometry and of exposure parameters, particularly kilovoltage. A method is described for proper choice of exposure kv which permits the high-quality radiographs needed for quality control. The joint design which proved to be most reliably manufactured (when a rigidly controlled process is (ollowed) is discussed. Author (NSA) 
"The aeronautical and space activities of the United States shall be conducted so as to contribute . . to the cxpansion of buman knowledge of phenomena in the atmosphere and space. The Administration shall provide for the widest practicable and appropriate dissemination of information concerning its activities and the results thereof."

-National aeronautics and Space Act of 1958

\section{NASA TECHNOLOGY UTILIZATION PUBLICATIONS}

These describe science or technology derived from NASA's activities that may be of particular interest in commercial and other nonaerospace applications. Publications include:

TECH BRIEFS: Single-page descriptions of individual innovations, devices, methods, or concepts.

TECHNOLOGY SURVEYS: Selected surveys of NASA contributions to entire areas of technology.

OTHER TU PUBLICATIONS: These include handbooks, reports, notes, conference proceedings, special studies, and selected bibliographies.

Details on the availability of these publications may be obtained from:

National Aeronautics and Space Administration

Code UT

Washington, D.C. 20546

Technology Utilization publications are part of NASA's formal series of scientific and technical publications. Others include Technical Reports, Technical Notes, Technical Memorandums, Contractor Reports, Technical Translations, and Special Publications.

Details on their availability may be obtained from:

National Aeronautics and Space Administration

Code US

Washington, D.C. 20546

\section{NATIONAL AERONAUTICS AND SPACE ADMINISTRATION Washington, D.C. 20546}

